BULLETIN Bulletin hispanique

HISPANIQUE Université Michel de Montaigne Bordeaux

115-1 | 2013

Poésie et société en Espagne : 1650-1750

\title{
Era una tarde de un jardín umbrío
}

trayectoria de un motivo finisecular entre poesía y pintura

Jesús Ponce Cárdenas

\section{(2) OpenEdition}

Journals

Edición electrónica

URL: http://journals.openedition.org/bulletinhispanique/2513

DOI: 10.4000/bulletinhispanique.2513

ISSN: 1775-3821

Editor

Presses universitaires de Bordeaux

Edición impresa

Fecha de publicación: 1 junio 2013

Paginación: 305-358

ISBN: 978-2-86781-898-1

ISSN: 0007-4640

Referencia electrónica

Jesús Ponce Cárdenas, "Era una tarde de un jardín umbrío », Bulletin hispanique [En línea], 115-1 | 2013,

Publicado el 01 junio 2016, consultado el 10 diciembre 2020. URL : http://journals.openedition.org/

bulletinhispanique/2513 ; DOI : https://doi.org/10.4000/bulletinhispanique.2513 


\title{
Era una tarde de un jardín umbrío: trayectoria de un motivo finisecular entre poesía y pintura
}

\author{
Jesús Ponce Cárdenas \\ Universidad Complutense de Madrid
}

Nada tan absurdo como el querer desligar las artes.

Juan Ramón Jiménez

Entre 1895 et 1920, certains peintres et poètes espagnols cultivent avec insistance un motif paysager commun: le jardin. Quand il leur faut fixer cet espace symbolique - entre Nature et Art-, les créateurs offrent une vision de ce motif qui reflète une attitude d'époque. Cet article analyse un corpus poétique et iconographique qui permet de retracer l'évolution de ces relations personnelles et inter-artistiques sous le signe du Symbolisme et du Décadentisme.

Mots-clés: jardin, poésie, peinture, fin-de siècle, S. Rusiñol, J. Sorolla, J. R. Jiménez, frères Machado, E. Marquina, A. de Zayas, F. Arévalo, F. López Martín, Symbolisme, Décadentisme.

Entre 1895 y 1920, varios pintores y poetas españoles cultivaron con asiduidad un motivo paisajistico: el jardín. La fijación de este espacio, a medio camino entre el arte y la naturaleza, permitió a los creadores dar cuenta de su personal visión del motivo. El presente articulo analiza un conjunto de imágenes y poemas mediante los cuales puede delinearse la trayectoria de esas relaciones personales e inter-artísticas bajo el signo del Simbolismo y el Decadentismo.

Palabras claves: jardín, poesía, pintura, fin de siglo, S. Rusiñol, J. Sorolla, J. R. Jiménez, hermanos Machado, E. Marquina, A. de Zayas, F. Arévalo, F. López Martín, Simbolismo, Decadentismo.

Between the 1890s and 1920s, some Spanish painters and poets developed a similar subject: the garden-landscape. These artists gave a personal vision of the design, fxing a space full of symbolic meanings between Art and Nature. This article analyses several images and poems in order to identify the evolution of the crossroads -both personal and interartistic-under the sign of Symbolism and Decadentism.

Keywords: garden, poetry, painting, the end of century, S. Rusiñol, J. Sorolla, J. R. Jiménez, hermanos Machado, E. Marquina, A. de Zayas, F. Arévalo, F. López Martín, Symbolism, Decadentism. 
$\mathrm{D}$ urante las postrimerías del Ochocientos y las décadas iniciales de la siguiente centuria los jóvenes maestros de la poesía modernista mantuvieron un diálogo intenso y fructífero con los pintores coetáneos. De la pasión de estos literatos por las artes plásticas y de su fascinación por la técnica de la écfrasis -o "descripción literaria de una obra de arte visual"- surgieron entonces volúmenes tan importantes como los Retratos antiguos (1902) de Antonio de Zayas o Apolo. Teatro pictórico (1911) de Manuel Machado. En las páginas de tales obras se describían, de manera bastante libre y lírica, lienzos de artistas tan diversos como Fra Angelico, Pisanello, Rafael, Tiziano, Tintoretto, Holbein, Velázquez, Goya, Reynolds, Romero de Torres... Mas la afinidad entre las artes plásticas y las artes verbales durante los años que median entre 1890 y 1920 no surgió únicamente de esta visión -muy circunscrita- de la écfrasis, sino que algunos "parallèles sémantiques ou thématiques» permiten «également de jeter des ponts entre peinture et littérature» ${ }^{1}$. Orillando algo el testimonio de unos libros poéticos nacidos de una inmediata incitación visual, a lo largo de las páginas siguientes nuestra atención se centrará en uno de los más significativos paralelos semánticos o temáticos que recorren las artes de la época: el jardín.

Con la sabrosa dicción que le caracteriza, Sebastián de Covarrubias acotaba en 1611 el sentido de la voz Jardín: «huerto de recreación de diversas flores y hierbas olorosas, con fuentes y cuadros repartidos con muchos lazos y obra que llaman los latinos topiaria, de mesas de arrayán y de otras hierbas» ${ }^{2}$. En los albores de la edad barroca, el famoso lexicógrafo daba las coordenadas principales que identifican un lugar donde se conjugan Naturaleza y Arte para deleite de los cinco sentidos. La transposición poética de ese espacio de recreación y sosiego alcanzó, de hecho, una de sus más altas cimas en la lírica española del siglo XVII: el Paraíso cerrado para muchos, jardines abiertos para pocos (1652) del granadino Pedro Soto de Rojas ${ }^{3}$. Algunos años antes de que el autor del Desengaño de amor en rimas elaborara su obra maestra, la tradición pictórica del jardín en España iba a ser inaugurada magistralmente por Velázquez (circa 1630). En efecto, la estancia del pintor sevillano en Roma dio ocasión a que éste realizara dos de sus lienzos más fascinantes y modernos: Jardín de Villa Médicis (Pabellón de

* Agradezco a los profesores Mercedes Blanco y Ángel Luis Luján Atienza la atenta lectura del original de este artículo, así como las valiosas sugerencias que me han hecho al respecto. Quisiera también manifestar mi gratitud a Barbara Guidi, Grégoire Polet y Federica Sani.

1. Liliane Louvel, Texte, image. Images à lires, textes à voir, Rennes, Presses Universitaires de Rennes, 2002, p. 19.

2. Tesoro de la lengua castellana o española, Martín de Riquer (ed.), Barcelona, Alta Fulla, 1998, p. 712.

3. Contamos con dos importantes ediciones del poema: El Paraíso comentado, José Fernández Dougnac (ed.), Granada, Ubago, 1992; Paraíso cerrado para muchos, jardines abiertos para pocos. Los fragmentos de Adonis, Aurora Egido (ed.), Madrid, Cátedra, 1993. La poesía descriptiva de jardines en el Barroco tuvo otros cultores ilustres, como Lope de Vega (Descripción de la Abadia, jardín del duque de Alba), Lupercio Leonardo de Argensola (Tercetos en que se describe Aranjuez), Baltasar Elisio de Medinilla (Descripción de Buenavista) y Hernández de Velasco (Selva de Aranjuez). 
Ariadna) y Jardin de Villa Médicis (Fachada de una loggia). Se ha atribuido al pintor de cámara de Felipe IV una exquisita originalidad en la propia elección del tema (el jardín concebido como pequeño cuadro de paisaje), en el estudio de la naturaleza y la luz como dos elementos que dialogan, así como en la técnica de manchas o borrones que emplea (fig. 1$)^{4}$. La ligereza de las pinceladas, su aparente condición de apunte del natural y la ejecución de ambas obras en plein air ha ocasionado que la crítica establezca conexiones entre estas pinturas y los jardines pictóricos del Ochocientos.
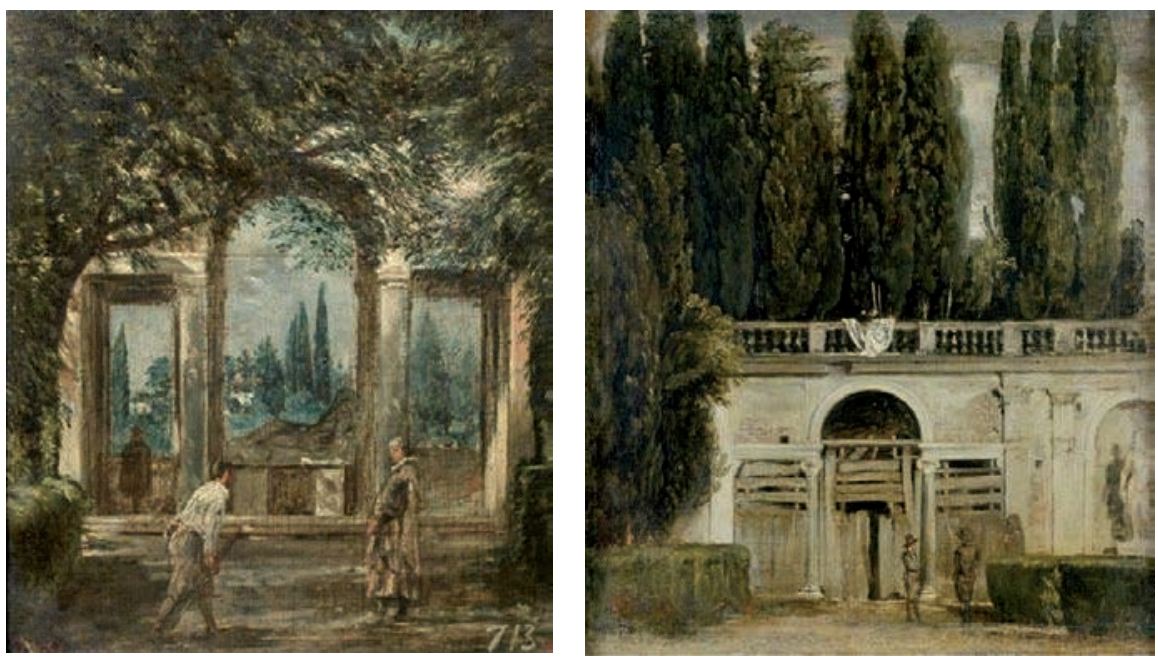

Fig. 1. Jardin de Villa Médici (Pabellón de Ariadna) y Jardín de Villa Médici (Loggia)

(C) Museo Nacional del Prado - Madrid - (España)

A la luz de estas imágenes, no parece arriesgado sostener que el motivo del jardín en la tradición española contaba ya con varios precedentes -visuales y poéticos- muy ilustres. Ahora bien, el sentido que se atribuirá a este locus intimus en las obras finiseculares se aleja mucho de su valoración clásica. Por todo ello, mediante el examen de algunas obras de Santiago Rusińol y Joaquín Sorolla, dispuestas en paralelo con el análisis de varias composiciones de los hermanos Machado, Antonio de Zayas, Juan Ramón Jiménez, Eduardo Marquina, Francisco Arévalo y Fernando López Martín, tratará de arrojarse alguna luz sobre una serie de documentos inter-artísticos que atribuyen al jardín una verdadera saturación de valencias simbólicas 5 .

4. Enriqueta Harris, «Velázquez and the Villa Medici», en Estudios completos sobre Velázquez, Madrid, C.E.E.H., 2006, p. 167-177.

5. A la hora de establecer el corpus textual en castellano se han circunscrito las muestras al ámbito estrictamente lírico. Sin duda, en otros campos literarios pueden hallarse manifestaciones afines, como la interesante crónica de viaje publicada por Rubén Darío en 1908 bajo el título de Jardines de Francia (recogida en la antología dariana El modernismo y otros ensayos, Iris M. Zavala (ed.), Madrid, Alianza, 1989, p. 199-200). También la narrativa breve del momento acoge piezas descriptivas excepcionales, como el jardín del Palazzo Gaetani en la Sonata de Primavera de 


\section{El JARDÍN MELANCÓLICO: RUSIÑOL}

El tema del jardín en la pintura y la literatura finiseculares conduce, ineludiblemente, hasta la figura de Santiago Rusiñol (Barcelona, 1861-Aranjuez, 1931), en su doble faceta de pintor y creador literario. El nombre de este artista aparece asociado a la llegada de la nueva estética moderna a la península, ya que a su iniciativa se debe la celebración de las denominadas Festes Modernistes de Sitges entre 1892 y $1899^{6}$. La pasión del creador catalán por el Ars Topiaria que reflejan sus lienzos se identifica con una geografía y un momento determinados: entre el trece de octubre de 1895 y el dieciséis de febrero de 1896 Rusiñol realizaba un viaje por tierras andaluzas que le hizo recalar en la granadina Fonda Siete Suelos ${ }^{7}$. Bajo la sugestión del otońo en la Alhambra, el pintor quiso prolongar su estancia en la ciudad del Darro y alquiló un Carmen en la avenida del Generalife junto a sus amigos Miguel Utrillo, Arcadi Mas, Macari Oller y el pintor francés Richard Richon-Brunet. Como apuntara un conocido crítico, «siempre que el tiempo se lo permitía -sus primeros días en Granada fueron [...] muy lluviosos- salía por las cercanías para hacer cuadros de paisaje plein ain ${ }^{8}$. El descubrimiento de la antigua urbe nazarí, la visión del esplendor decadente de la Alhambra y la estampa melancólica de los jardines del Generalife dejaron en el pintor una huella indeleble. Entre las Cartas de Andalucía que Rusiñol publicara en La Vanguardia, cabe recordar ahora aquella que lleva por título El Generalife, impresa el veintiocho de noviembre de 1895 y recogida posteriormente en el volumen de Impresiones de arte. Al hablar de los soberbios jardines árabes, trazaba la siguiente pintura verbal:

¿Qué misterio tendrá el Generalife que tan solo su nombre nos evoca tantos ensueños? ¿Qué contendrán aquellos blancos muros, que a su sola memoria cantan los poetas, entornan los ojos las mujeres, se quedan pensativos los hombres y se enturbian las cabezas más serenas? [...]. Llegado ya con el ansia con que se acude a una cita artística, con ese afán del que va a

Valle-Inclán (Sonata de primavera. Sonata de estío, Madrid, Espasa-Calpe, 1991, p. 36-37). Por motivos de espacio, no podemos detenernos aquí en ese otro tipo de manifestaciones literarias. Ahora bien, como valoración global del motivo en esta cronología puede verse la panorámica esbozada por Ana Suárez Miramón: «El jardín como mosaico de sensaciones naturales y estéticas», El Modernismo: compromiso y estética en el fin de siglo, Madrid, Laberinto, 2006, p. 176-183. De mucha menor relevancia resulta el trabajo de Rebeca Siegel, «Hacia una hermenéutica del jardín», Angélica. Revista de Literatura, 9, 1999, p. 97-111.

6. Las cinco veladas tuvieron lugar el 23 de agosto de 1892, el 10 de septiembre de 1893, el 4 de noviembre de 1894, el 14 de febrero de 1897 y el 5 de julio de 1899 . Una valoración de las mismas ofrece Giovanni Allegra en "Las festes modernistes», El reino interior. Premisas y semblanzas del Modernismo en España, Madrid, Ediciones Encuentro, 1985, pp. 128-131. Puede consultarse asimismo en esta monografía las reflexiones dedicadas a «Santiago Rusiñol en París», p. 124-128.

7. Vinyet Panyella, "Andalusia vista per un catalá», Paisatges $i$ escenaris de Santiago Rusiñol (París, Sitges, Granada), Barcelona, Publicacions de l'Abadia de Montserrat, 2000, p. 91-161.

8. Miguel D’Ors, «Santiago Rusiñol», en Posrománticos, Modernistas, Novecentistas. Estudios sobre los comienzos de la literatura española contemporánea, Sevilla, Renacimiento, 2005, p. 114131. 
recoger impresiones en pos de una novela que sólo se conoce por retrato, con esa indecisión de la esperanza que teme el desengańo, mirando la silueta del palacio dormitando entre jardines, nos acercamos a él y penetramos por una sencilla verja sombreada por nogales. A poco penetramos en un paseo de cipreses que recortados en cilindro y formando en dos hileras, cual dos muros de finísimo follaje, cierran el ánimo a toda contemplación que no sea el Generalife. Espesos, bruñidos de ese verdor perenne y modelado que tienen los viejos jardines, con esa pátina de abolengo, con esa forma impuesta a los caprichos de árbol domado por educación aristocrática, explica al viandante que allí no se entra en un jardín advenedizo, sino en alcázar perfumado por la mano del artista y las caricias del tiempo. Largo el muro como visión de Maeterlinck, se anda por un corredor severo y blandamente arenado, y al doblar una esquina, se domina el paseo de cipreses más soberbios de la tierra. Árboles centenarios, carcomidos de vejez, que vieron pasar por sus plantas la vida íntima de los reyes de Granada [...]. Allí está el Generalife. Se abre una pequeña puerta y al entrar en el recinto, un aroma inexplicable, un aire impregnado de poesía, un murmullo de agua saltando sobre la piedra, una brisa que hace gemir y cantar las hojas, una mirada de las flores, un no sé qué que llega en vibraciones de luz, envuelto en modelada armonía, deja suspenso al que entra, le hace gozar de un algo maravilloso y abre las puertas a los ávidos sentidos. En primer término una taza de mármol, estriada como una concha y rodeada de macetas mirándose reflejadas; a cada lado, dos columnitas mates y amarillentas como cuello de mujer; con sus tenues capiteles sosteniendo tres arcos en sus débiles espaldas; a un lado, un muro oculto detrás de laureles y naranjos; al opuesto una larga y diminuta galería de un blanco de reflejos de oro arqueándose hacia el fondo; en el centro, un canal tranquilo como una fuente y alegre como un riachuelo, escurriéndose callado y asomándose a sus aguas hasta besarlas y sentir la frescura en sus hojas y corolas, un rubio campo de flores; rosas de otońo de un carmín tornasolado, crisantemos despeinados revolcándose y desperezándose por el suelo, geranios como puntos encendidos, claveles desbordando sobre un lecho de verdura, y en el fondo, cerrando este jardín sin igual, cinco arcos seguidos de otros arcos, calados con primores de ornamentación geométrica y arabescos como blondas, y todo ello pequeño como un claustro bizantino, recogido, callado como un secreto, suave de colores como un traje de virgen primitiva, melancólico como un canto oriental, con luz velada de patio y esplendores de aire libre, y todo hecho a propósito para hablarse con misterio, acompañada la voz por arrullo delicioso?

En esta suerte de notas de viaje, Rusiñol da cuenta de sus primeras sensaciones ante un jardín antiguo y asocia dicho espacio cerrado con «un aire impregnado de poesía», con el «misterio» y la «contemplación», con el «secreto», con el espíritu lánguido y «melancólico» de un «canto oriental», con las «rosas de otońo» y los «cipreses soberbios» (fig. 2) ${ }^{10}$. Desde el punto de vista de los paralelos inter-artísticos que traza el creador en este cincelado párrafo, cabe subrayar que, ante sus ojos, una parte del jardín antiguo se asocia a la poética simbolista, puesto que se asemeja a una «visión de Maeterlinck». Años más tarde el artista habría de confesar a Josep Pla que -a su juicio- sólo en los jardines de Granada late la verdadera poesía: «de los jardines que pintó [Rusińol], los que más le gustaron fueron los de Granada. Solía decir que

\footnotetext{
9. S. Rusiñol, Obres completes, Barcelona, Editorial Selecta, 1976, vol. II, p. 779-780.

10. La vista de los jardines del Generalife que lleva por título Soledad. Granada fue expuesta por vez primera en los salones del diario El Defensor de la ciudad andaluza (1898). Sobre la fascinación que despiertan los ambientes granadinos en el fin de siglo, véase la sintética reflexión de Lily Litvak, "La Alhambra», El sendero del tigre. Exotismo en la literatura española de finales del siglo XIX (1880-1913), Madrid, Taurus, 1986, p. 67-70. De obligada lectura resulta asimismo el estudio de Annick Le Scoëzek Masson, «Jardins modernistes: les dissidences du moi autour de 1900", en Françoise Le Borgne, Simone Bernard-Griffiths y Daniel Madélenat (éds.), Jardins et intimité dans la littérature européenne (1750-1920), Presses Universitaires Blaise Pascal, 2008, p. 467-480 (en especial p. 467-469).
} 
la mayor parte de los jardines que compuso -en Italia, Mallorca, Valencia, Gerona, Barcelona, Aranjuez- eran obra de arquitectos y jardineros. Sólo los de Granada parecían haber sido hechos por poetas ${ }^{\prime 1}$. Nacía así el proyecto de abordar un complejo ciclo de pinturas dedicado en exclusiva a los jardines -muchos de ellos en estado de postración y abandono- de varias ciudades españolas.

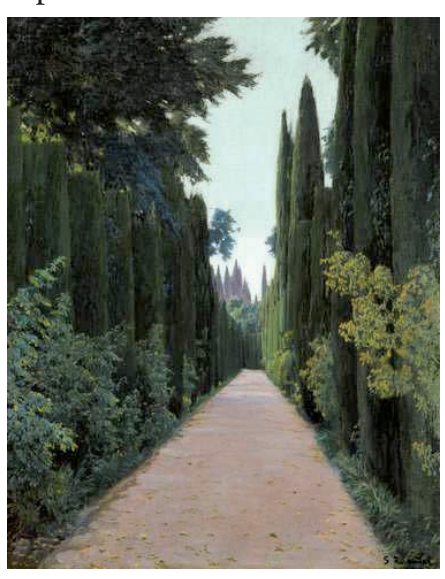

Fig. 2. S. Rusiñol, Soledad. Granada (colección particular).

También durante la otoñal estancia granadina se gestó una de las obras literarias más ambiciosas del polifacético artista: Oracions (impreso en 1897). El libro nacía de la colaboración de tres amigos que intentaron como «creadores modernos» elaborar un verdadero breviario de belleza: Rusiñol, autor de los poemas en prosa; Miquel Utrillo, que firmaba las ilustraciones y Enric Morera, que compuso varias partituras intercaladas entre las páginas del volumen. Oracions se erigía, pues, en una obra que aspiraba a la fusión de las artes, al tiempo que a ojos de sus contemporáneos aparecía marcada con los signos inequívocos del «decadentismo», la «extravagancia» y la "fermentación morbosa»"

Por cuanto ahora nos interesa, una de las más sugestivas viñetas del libro lleva por título An els jardins abandonats y la crítica ha reconocido en este poema en prosa la quintaesencia de los cuadros del propio pintor. Bastará con evocar alguno de sus párrafos para verificar cómo entre evocaciones melódicas se traza aquí uno de los perfiles definitivos del motivo del jardín en decadencia:

A l'entrar en un jardí abandonat, l'aroma de ruïnes que es respira, de frescor marcida, de flor esfullada, d'heura i de murtra, fan gaudir l'esperit de l'essència d'una obra d'art, envellida i poetitzada. D'aquelles plantes nascudes de noble saba, creixent amb el bon gust que el llegà son passat, enfilant-se per les branques i caient amb delitosa indolencia; de les parets de xiprers despentinant-se en garbes d'espessa molsa; de les flors esclatades, plovent amb colors malalts i sembrant la terra de fulles, se'n desprèn un perfum de voluptuositat perduda, de seda despintada, de saba esmortuïda pel vent de l'abandono; dels brolladors eixuts, amb la gleba assecada; de les amples escalinates amb les lloses mogudes per l'empenta de l'herba creixent entre les juntures dels balustres trencats; de les blanques estàtues de marbre, daurades de la pàtina del sol i ombrejades dels petons freds de la lluna, en destilla l'enyorament de la riquesa pasada i la gran tristor de la grandesa caiguda; dels caminals alfombrats de margarides silvestres, dels esbarzers de fora mirant sobre la tàpia, de les pobres fulles seques arrupides de fred sobre l'estany sense aigua, ne cauen tendres llàgrimes; dels sàtirs caiguts, dels gerros esquerdats, de les lloses trencades, de la terra que s'infla i els arbres que es desborden, ne queda un record de

11. Josep Pla, Santiago Rusiñol y su época, Barcelona, Ediciones Destino, 1989, p. 175.

12. Miguel de Unamuno reseńó la obra en La Época (16-I-1898), destacando su importancia. En su larga recensión se hizo eco de tales valoraciones. Tomo la información del libro de Margarida Casacuberta, Santiago Rusiñol: vida, literatura i mite, Barcelona, Publicacions de l'Abadia de Montserrat, 1997, p. 211. 
noblesa, de pàtina severa, de distinció suprema: la distinció de l'obra d'art madura portant el sentiment d'una hermosa agonía i el record de ventures fugides [...]. Aquest contacte amorós que palpita del fons d'aquelles viventes ruïnes; el rastre de grandesa morta entre els arbres que es renoven; l'ambient que corre entre solituds que parlen, dóna potser, als jardins abandonats, la tristesa de tota obra d'art caiguda quixant-se amb veu de llegenda [...]. Aneu-hi, que vostre cor gaudirà el lirisme de les línies grandioses escrites a pinzellades solemnes; entirà l'aroma marcit i tebi amb vaguetats decadents d'essències esmortuïdes; rebrà el consol i el repòs de l'obra ja envellutada per la dolçura del temps i el segell de sa noblesa, i la fonda impressió que inspira la solitud dels passatges que expliquen sa vella historia amb estrofes de madura poesia. Aneu-hi sovint a sentir-la, somniadors de la terra; aneus a aquell museu fet d'essència de paisatge ; anem-hi tots a resar per la bellesa enterrada en son mateix cementiri ${ }^{13}$.

El poema en prosa proporciona una serie de claves para identificar el trasfondo simbolista, que permite asimismo «leer» los cuadros de esta época: el jardín abandonado es una obra de arte poblada por el «aroma de las ruinas» al tiempo que ofrece a la vista "un recuerdo de nobleza», de "suprema distinción» que destila "tristeza", pues se erige en "cementerio" de su propia hermosura ${ }^{14}$. En una reseña publicada el dieciocho de septiembre de 1897, J. M. Jordá relacionaba el tono flébil de estas prosas líricas, la vaguedad, el aire decadente y enfermizo de sus estampas con el magisterio de Verlaine y Mallarmé.

Como se ha podido observar, a partir del año 1896, el jardín en decadencia llegó a convertirse en el elemento capital de la obra plástica y literaria del creador barcelonés. Después de un trienio de febril actividad, entre octubre y noviembre de 1899, con la exposición titulada Jardins d'Espagne, Rusiñol obtenía un clamoroso éxito en París, en la sala L’Art Nouveau de Sigfried Bing, y establecía así un primer hito en este desarrollo temático. Uno de los maestros de la literatura francesa del fin de siglo -Jean Lorrain- definía los cuadros del artista catalán en los siguientes términos:

La manera de Rusiñol puede compararse con la de Montenard, pero su obra-inferior como técnica- es mucho más impresionante. Se desprende de ella otra melancolía, la melancolía de soledad y de tristeza opresora de las monarquías decrépitas, una tristeza adormilada de los parques reales, inmovilizados en el silencio, como embalsamados en calor y abandono. Versalles españoles, marcados por esta especie de muerte que parece haber caído, en los países de raza latina, sobre toda la obra de los Borbones: Borbones de Francia, Borbones de España, dinastías cuyo sudario se arrastra y pesa en las alamedas rectas de Aranjuez como en los boscajes de Trianon ${ }^{15}$.

El éxito de la mostra parisina se repetía en noviembre de 1900, cuando se inauguraba en la Sala Parés de Barcelona la exposición de sus Jardins d'Espanya. Datada en la ciudad condal ese mismo año, una composición juvenil de Eduardo Marquina (Barcelona, 1879-Nueva York, 1946), titulada Jardines de España, celebraba en dísticos alejandrinos el talento del pintor modernista:

Silenciosos caminos, sońolientas arcadas, inmóviles estanques y ventanas cerradas:

13. S. Rusiñol, Obres completes, Barcelona, Editorial Selecta, 1976, vol. I, p. 28-29.

14. Lourdes Sánchez Rodrigo, Oracions a la natura: la prosa poética de Santiago Rusiñol, Sitges, Grup d'Estudis Sitgetans, 1992. Puede consultarse asimismo la reciente traducción de L. Sánchez Rodrigo: Oraciones, Castellón, Ellago Ediciones, 2005.

15. Santiago Rusiñol, Madrid, s. f., p. 17-18. 
nada vive entre medio de la intensa verdura, para tus cuadros tristes no queda una figura.

Damiselas perdidas de vaporosos trajes y lechuguinos dándose aire de personajes; condesas de una rancia vejez; grandes de España encorvados al peso de una estupenda hazaña.

Todo aquel mundo viejo, solitarios jardines, que bulliciosamente llenó vuestros confines ha desaparecido, sin daros descendencia. ¡Oh abominados padres que no dejáis herencia!

En apenas doce versos, el poeta logra recrear la atmósfera de las pinturas del artista barcelonés mediante una reveladora adjetivación que incide en nociones como el silencio, el sueño, el estatismo, la clausura, la tristeza y la soledad ${ }^{16}$. Según revelan estos alejandrinos, los jardines de Rusiñol se ofrecen como agónico vestigio de un mundo casi desaparecido (el de la aristocracia) y reflejan -por obra y gracia del arte- mediante unos «cuadros tristes» sin «figura» el espacio de la decadencia y la melancolía. De singular interés nos parece que el texto de Marquina evoque, a un tiempo, la serie de cuadros expuesta en la capital francesa y la ambientación decadente y opresiva del «cuadro poemático» en un acto El jardin abandonado, que Rusiñol había presentado en una lectura ante la Agrupación Catalanista de Sitges durante el verano de 1899 y que diera poco después a las prensas en Barcelona, a comienzos de abril de $1900^{17}$.

El éxito de esta importante serie de lienzos motivó que en 1903 se imprimiera un importante conjunto de reproducciones de sus pinturas en el catálogo titulado Jardins d'Espanya ("gravat y estampat a cân Thomas, de Barcelona, l'any MCMIII»). De las cuarenta imágenes de jardines allí recogidas, diecisiete son de origen granadino, catorce de enclaves de Mallorca, dos proceden de Tarragona, otros tantos de Aranjuez y finalmente un solo jardín tiene su origen en Valencia, La Granja, Barcelona, Sitges y Montserrat ${ }^{18}$. El testimonio de los Jardines de España resulta capital para comprender la aclimatación del motivo a la lírica del fin de siglo, ya que el volumen estaba encabezado por unas palabras liminares del creador que pueden verse bajo la especie de una personalísima declaración de poética: «Morían los jardines viejos, pero morían con tanta nobleza que de su muerte brotaba una poesía nueva: la poesía de las grandezas caídas» ${ }^{19}$. Por si ello fuera poco, la obra iba acompañada de un notable conjunto de poemas, donde figuras tan relevantes como Joan Maragall, Gabriel Alomar y Apeles Mestres

16. Una interesante valoración del poema ofrece Margarida Casacuberta en Santiago Rusiñol: vida, literatura i mite, Barcelona, Publicacions de l'Abadia de Montserrat, 1997, p. 286-287.

17. Margarida Casacuberta, Santiago Rusiñol: vida, literatura i mite, Barcelona, Publicacions de l'Abadia de Montserrat, 1997, p. 275-282.

18. Algunos de estos cuadros fueron expuestos de nuevo con ocasión del centenario de la primera exhibición de las pinturas. El catálogo moderno se titula: Santiago Rusiñol. Los jardines del alma, Girona, Caixa de Girona y Caja Segovia, 1999.

19. Cito de la publicación en castellano: Jardines de España, por Santiago Rusiñol, Madrid, Renacimiento, 1914, p. 3. 
- por espigar tan sólo unos nombres significativos- se inspiraban en elementos pictóricos de la obra de Rusiñol para trazar sus versos.

El libro de arte de 1903 tuvo una exitosa acogida por parte de la crítica modernista, de forma que algunos años después se realizó una segunda edición ampliada del mismo. Junto a las ocho poesías en catalán de Alcover, Alomar, Costa, Llobera, Guanyabéns, Mestres, Maragall, Matheu y Oliver, el volumen acogía ahora siete poemas en castellano: la Oración en el jardín, de Enrique Díaz Canedo; el Año sentimental de Francisco A. de Icaza; Granada de Manuel Machado; Los jardines de España de Eduardo Marquina; A Santiago Rusiñol de Gregorio Martínez Sierra; Jardines de Ramón Pérez de Ayala y A Santiago Rusiñol. Por cierta rosa de Juan Ramón Jiménez ${ }^{20}$. Pese a su indudable interés, no podemos extendernos en el examen de esta profusa serie, mas resulta obligado señalar cómo la importancia que asumen los jardines granadinos en el ciclo pictórico tendría también un interesante reflejo en el ámbito de los homenajes líricos. De hecho, el tributo ecfrástico que Manuel Machado consagrara al pintor se centra precisamente en la imagen de la ciudad nazarí:

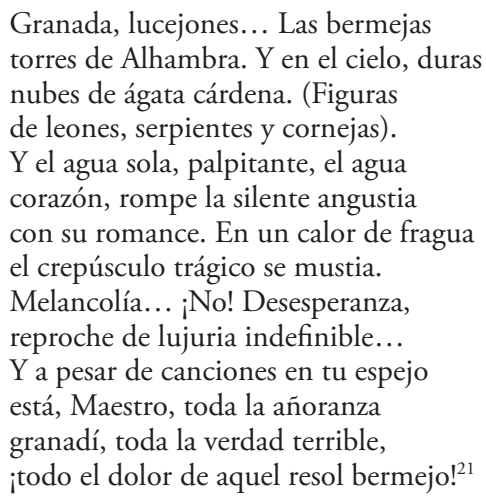

La interpretación de la pintura rusiñoliana que da el autor de Apolo incide en nociones propias del mal del siglo, como la «angustia», la «melancolía» o la desesperación, asociándolas a la mórbida «lujuria» y la «añoranza». El color rojizo de la urbe nazarí aparece envuelto entre los versos en el oro enfermizo de un "crepúsculo trágico», ya que el artista ha logrado revelar a través de sus imágenes «la verdad terrible» que identifica a la ciudad muerta y el «dolor» de su sol rojo.

La sugestiva transposition d'art de Manuel Machado puede disponerse en paralelo con una evocadora composición en versos alejandrinos de Juan Ramón Jiménez ${ }^{22}$ :

20. Entre las cuarenta y un imágenes recogidas en la edición castellana, puede anotarse cómo cobran suma importancia dos elementos vegetales entre las obras escogidas (el ciprés y la rosa): Camino de rosales (Aranjuez), Camino de rosas (Mallorca), Cipreses del Generalife (Granada), Cipreses dorados (Granada), Nido de cipreses (Aranjuez), Cipreses viejos (Granada).

21. Jardines de España, por Santiago Rusiñol, Madrid, Renacimiento, 1914, p. 13.

22. Jardines de España, por Santiago Rusiñol, Madrid, Renacimiento, 1914, p. 21. Las estancias de Jiménez en Francia (donde el renombre del pintor catalán era grande) durante los primeros 
Mira, Maestro, este solitario paraje quieto y hondo, tan dulce de luz y de verdores como aquellos de paz, de ternura, de encaje, en que tu corazón soñara los colores.

Su ocaso vago tiene tu doliente elocuencia, tu oración de otras tardes en su cenit persiste, se hunde en la noche azul con aquella demencia de nostalgia que tú callando nos dijiste.

El agua que en el fondo de esta gruta, obstinada cual en un reloj triste, cóncavamente llora, refresca la penumbra con la esencia mojada que enredó a sus misterios tu alma embalsamadora.

Y, cielo abierto en flor, Venus clara y celeste, esta rosa, en su tallo de un verde no aprendido, recoge la luz última del crepúsculo este que parece que tú otra vez, has sentido;

fantasma de matices, doncella que trocase, voluble, su oro en plata, su plata en violeta, como si, en un anhelo de encantos, imitase tu corazón romántico de pintor y poeta...

Decoración de ensueño ya mirada de estrellas, donde el surtidor pálido al cielo se levanta, mientras el ruiseñor, loco de penas bellas, quieto frente a la rosa que tú has pintado, canta.

¡Soledad que el amor deja al arte! ¡Sombrosa senda en que vaga aún tu pincel vespertino! ¡Glorieta de pasión, en que es reina tu rosa de un mundo más pequeño, más dulce y más divino!?3

El arranque del poema se antoja revelador por varios motivos: en primer lugar, por el empleo de un marcador escópico, acompañado de un deíctico de cercanía. Ambos elementos forman una clara invitación a contemplar un lienzo concreto: «Mira este paraje solitario» ${ }^{24}$. En segundo plano, el apóstrofe con que se dirige al pintor ańade al alejandrino inicial un matiz de reconocimiento,

ańos del nuevo siglo, así como las lecturas de revistas y libros de arte surgidos en Barcelona debió de servir como puente entre ambos creadores. La relación entre el poeta y el artista debió de hacerse más profunda en los años 1903-1904, con ocasión de la adhesión común al proyecto de la revista Helios. Como presentación general de la materia, cabe remitir al trabajo de José María Balcells, "Jardines abandonados en Juan Ramón y en Santiago Rusiñol», Caligrama. Revista insular de filología, 3 (1991), p. 31-58.

23. Consignaré aquí algunas variantes entre la primera edición del poema y su versión definitiva: v. 13 «Y, cielo abierto en flor, luna clara y celeste»; v. 17 «tierna rosa alegórica, doncella que trocase»; v. 20 «tu corazón fantástico de pintor y poeta».

24. La deixis de proximidad se reitera en otros pasajes de la composición: «recoge la luz última del crepúsculo este». 
como si le ofrendara un tributo de admiración y homenaje, ya que concede a Rusiñol el honroso título de "Maestro», al igual que Manuel Machado en el poema Granada. Por otra parte, los versos juanramonianos inciden en una serie de nociones y clichés que evocan un ambiente desierto y enfermizo, un entorno de ensoñación: "solitario paraje», «tu corazón soñara», «doliente elocuencia», «aquella demencia de nostalgia», «decoración de ensueńo», «loco de penas»... El tema de la enajenación y la melancolía parece insinuarse en la écfrasis ensayada por el lírico de Moguer, que vincula además las pinturas a un momento del día: el «ocaso vago», la «oración de otras tardes», «la luz última del crepúsculo» ${ }^{25}$. Gracias a dicho detalle puede intuirse en el marco del poema la presencia de una fértil alianza icónico-literaria, que permitiría vincular las vagas sugestiones de los jardines pintados de Rusiñol con los cuadros poéticos ensayados magistralmente por Verlaine en la pequeña «colección» titulada Paysages tristes. La vaguedad melancólica de los alejandrinos del escritor español evoca la suave tristeza vespertina de poemas como Soleils couchants, Crépuscule du soir mystique, la celebérrima Chanson d'automne o Le rossignol. De hecho, este último texto se cierra con una escena muy similar a la de Jiménez (un paisaje nocturno en el que resuena el canto triste de un ave): "Nuit mélancolique et lourde d'été, / pleine de silence et d'obscurité, / berce sur l'azur qu'un vent doux effleure / l'arbre qui frissonne et l'oiseau qui pleure» ${ }^{26}$.

Podría afirmarse que en su indagación estética y meditativa en torno al motivo, Rusińol llegó a acuñar un verdadero molde (expresivo y tópico) para el jardín finisecular, por ello no estará de más recordar aquí las aseveraciones que establecía entre sus Impresiones de arte:

Considero tan importante el aspecto de los jardines para juzgar el carácter de una época, que basta imaginarse un estilo para ver el fondo de verdura que le cuadra [...]. Los jardines modernistas los imagino formados de árboles de abolengo y plantas espirituales y de sentido simbólico: grandes laureles, mirtos, cipreses y laureles rosas, en severos muros y cerrando la vista a toda vulgar perspectiva, lilas y lirios alineados y plantas acuáticas dormidas sobre estanques quietos y misteriosos, grupos de flores, formando con sus colores el arco iris, o

25. María Ángeles Heras Lázaro, «Juan Ramón Jiménez y Santiago Rusiñol: dos modernismos en diálogo", IV Congreso de Post-graduados en Estudios Hispánicos, Universidad de Nottingham, 1996, p. 79-88.

26. Paul Verlaine, Fêtes galantes. Poèmes saturniens, Paris, Gallimard, 2005, p. 70. Curiosamente, el magisterio verlainiano se funde en este poema con los recuerdos de uno de los más célebres sonetos gongorinos. En efecto, los versos «fantasma de matices, doncella que trocase, / voluble, su oro en plata, su plata en violeta» se inspiran libremente en las imágenes de los tercetos de la composición que Góngora concibe como un carpe diem dirigido a una bella muchacha («Mientras por competir con tu cabello»): "Goza cuello, cabello, labio y frente, / antes que lo que fue en tu edad dorada / oro, lilio, clavel, cristal luciente, / no sólo en plata o viola trocada». Sonetos completos, Biruté Ciplijauskaité (ed.), Madrid, Castalia, 1992, p. 230. De hecho, las presencias de la tópica áurea en los Jardines lejanos puede reconocerse en varios pasajes de la obra. Por ejemplo, en el poema XXV, donde la perdición se identifica con la boca de una mujer hermosa según los parámetros clásicos del latet anguis in herba (tan del gusto gongorino): «Iba vestida de gris / bajo un sombrero de rosas; / cuando el sol la acariciaba, / se le reía la boca [...]. / Cuando me dijo que sí / -aquel sí de mariposa- / le vi la lengua de víbora / en la rosa de su boca». Jardines lejanos, Madrid, Visor-Diputación de Huelva, 2007, p. 81-82. 
agrupadas en tonos complementarios y todo envuelto en un místico aroma de refinado buen gusto, todo mate y nadando en vaga neblina, como orquesta afinadísima de tintas, donde el alma gozara un absoluto reposo ${ }^{27}$.

El magisterio que Rusiñol ejerciera en el desarrollo poético del jardín en decadencia (perceptible en los elogios que le tributan -a modo de écfrasisMarquina, Machado o Jiménez) puede extrapolarse a otros ámbitos. De hecho, más adelante, la valoración de estas imágenes de jardines en decadencia también daría origen a unas pequeñas prosas poéticas de Gregorio Martínez Sierra. En la colección Monografías de Arte, el citado dramaturgo prologó dos volúmenes consagrados a la pintura rusińoliana (Paisaje y Figura). Siguiendo las pautas establecidas por el artista en su poema en prosa (En los jardines abandonados), Martínez Sierra realizaba una sugestiva conexión entre los jardines en decadencia y el motivo clásico de las ruinas:

Estos jardines vetustos que Rusińol elige como tema preferente para su inspiración, están precisamente despojándose, a fuerza de vejez y de abandono, de su elemento humano, la premeditación del hombre que los trazó, para volver a unirse con la tierra madre. Las arquitecturas se derrumban, las esculturas se desmoronan, el ciprés se carcome en las glorietas, el agua se evapora en los estanques o se filtra a través de las grietas de las tazas. Silenciosamente, la naturaleza vuelve a apoderarse de lo que es suyo... Hay un tenaz proceso dramático, que parece muerte, y en realidad es triunfo; los jardines se extinguen ahogados por la vida que no muere, o mejor dicho, se tienden al morir, acogiéndose al regazo de la madre tierra y envolviéndose en su manto piadoso ${ }^{28}$.

A juicio de Martínez Sierra, la tensión entre el Arte y la Naturaleza que da lugar al jardín se resuelve -en estos espacios abandonados- a favor de las potencias terrenas. La Naturaleza toma posesión de las bellezas antiguas y las ordena a su modo, estableciendo así una suerte de suntuoso Trionfo della morte, según las claves de la estética dannunziana ${ }^{29}$.

Como pequeño pórtico al examen de algunos lienzos del creador catalán, pueden aducirse ahora las reflexiones de Lily Litvak:

Los elementos que aparecen en el jardín pintado son constantes. Se favorece el tema del parque clásico, regido por la ordenación geométrica de las plantas, donde se reconstruye un mundo de formas y colores a la medida del hombre. Se modela el espacio, privilegiando la arquitectura que define el lugar, la vegetación podada en formas regulares, y las estatuas que toman posesión del aire con su masa o su empuje. Algunos cuadros muestran las verjas, rejas y muros que cierran el lugar, o son protagonistas principales las fuentes y su ornamentación estatuaria. Otros lienzos destacan elementos escenográficos; niveles, terrazas que permiten la exploración del espacio, anfiteatros, pórticos, arcos, columnas, pérgolas que producen una curiosa mezcla entre jardín y teatro. El tratamiento del fondo vegetal en corte topiario que expresa una confusión metamórfica entre el arte y la naturaleza es motivo de experimentaciones. Las arquitecturas vegetales ocupan mucho espacio; murallas de ciprés, setos de boj, arcadas,

27. S. Rusiñol, Obres completes, Barcelona, Editorial Selecta, 1976, vol. II, p. 793.

28. Santiago Rusiñol, Paisaje, Madrid, Monografías de Arte, s.f., p. 11.

29. Sobre la tradición de las ruinas en España es obligado remitir a una importante monografía de María Dolores Martos Pérez, Las ruinas en la poesía española contemporánea. Estudio y antología, Málaga, Universidad de Málaga, 2008. 
nichos, pilares y cornisas logrados con el ramaje de los arbustos, pequeños salones y cuartos de follaje domesticados por medio del artificio de la poda. La natura artificiosa destilada así es una abstracción, opuesta a la natura naturans que sigue el flujo del tiempo ${ }^{30}$.

La poética visual del ars topiaria en la obra de Rusiñol puede reconocerse en el espacio melancólico del Jardín de las elegías (h. 1903), donde puede contemplarse la alberca de la finca mallorquina del archiduque Luis Salvador de Austria: Son Moragues (fig. 3) $)^{31}$.

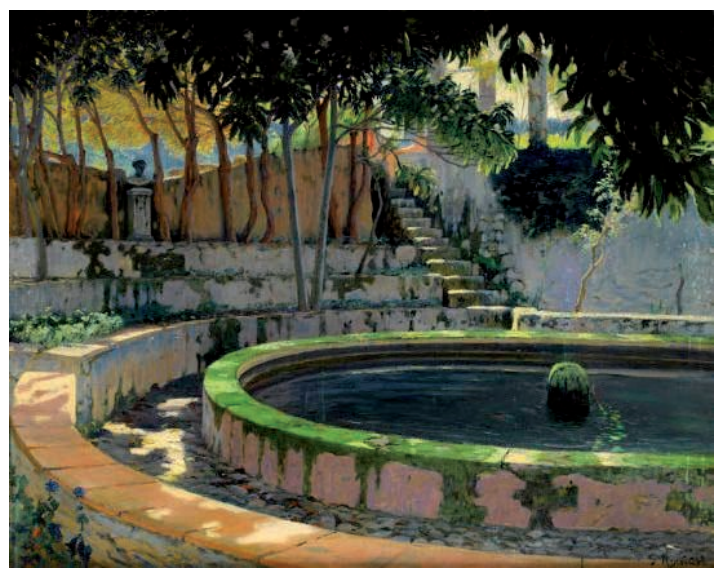

Fig. 3. Jardín de las elegías (colección particular)

El Jardin de las elegias presenta la masa circular de la alberca en la penumbra, ocupando la mitad inferior de la escena, según una estructura concéntrica. El juego luminoso que surge de los reflejos sobre la lámina de agua desempeña un importante papel en la definición de la arquitectura circundante. El denso follaje de los árboles equilibra la composición y teje un paramento de verdinegra sombra en todo el cuarto superior del lienzo. El escorzo de una escalera en la sección central y la presencia aislada de una herma ante un murete vegetal contribuyen a dotar de una sensación de profundidad al cuadro. En este escenario melancólico se sitúa en primerísimo plano el humilde surtidor de agua, cubierto por las sombras y en claro estado de deterioro, como evidencian el verdín y el musgo del graderío. La imagen parece situarse así bajo la advocación de lo elegíaco, conformando un espacio en el que impera el paulatino deterioro, el lánguido olvido.

Un juego afín de círculos concéntricos puede reconocerse en el cuadro Jardín de Aranjuez con el fauno viejo (fig. 4). La solitaria escultura ocupa el centro exacto de la visión, rodeada por un conjunto de recortados setos que semejan ondas concéntricas en una superficie vegetal. Las indistintas masas de la fronda arbórea ocupan el plano superior de la escena.

30. «El jardín abandonado. El tema del viejo parque en pintura y literatura», Espacio, Tiempo y Forma, XIII, 2000, p. 485-507. La cita se localiza en p. 489.

31. Subastado por la casa Sotheby's en 2010. 


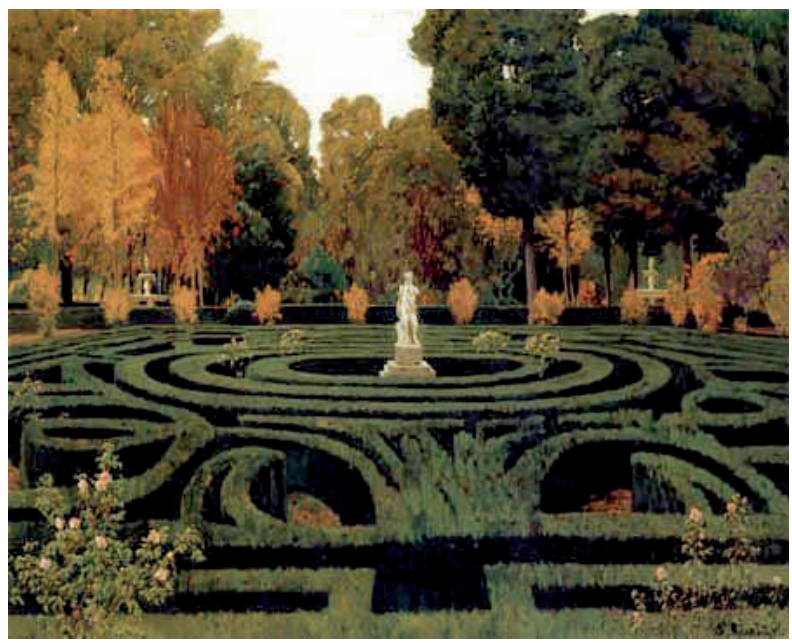

Fig. 4. Jardin de Aranjuez con el fauno viejo

(Museo Nacional-Centro de Arte Reina Sofía)

Junto a la sugestión del jardín granadino, el balear o el madrileño, podría contemplarse ahora otro ambiente sereno y majestuoso, poblado por estatuas (fig. 5). Se trata de un lienzo algo más tardío, de 1919, Jardines Monforte (Valencia).

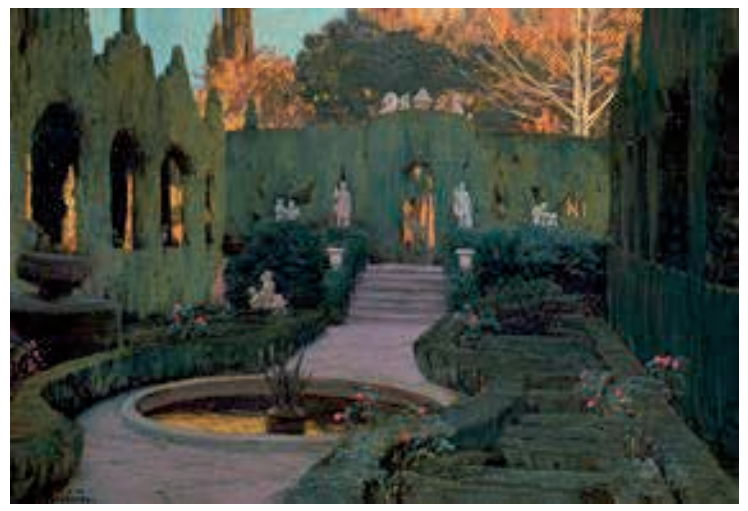

Fig. 5. Jardines Monforte, Valencia. Colección BBVA

La imagen aparece enmarcada por una doble galería vegetal, que abraza con varios puntos de sombra una perspectiva en diagonal que guía la vista de los espectadores hacia un conjunto de estatuas que ornan una pequeña escalinata. De nuevo, en primer plano, una fuente refleja en sus aguas el oro cansino de la luz cenital, tamizada asimismo en varios puntos del verdinegro pórtico.

Este pequeño conjunto de imágenes puede dar alguna idea sobre la poética de la melancolía que late en los lienzos de Rusiñol. Tanto las prosas críticas como los elogios poéticos que suscitaron tales cuadros inciden una y otra vez en la identificación de las imágenes como «cuadros tristes» de «solitarios jardines», 
como lienzos de los que se desprende «la melancolía de soledad y de tristeza opresora de las monarquías decrépitas, una tristeza adormilada», como escenas plásticas que hablan al espectador con "doliente elocuencia» hasta sumirlo en una verdadera «demencia de nostalgia».

\section{LA VISIÓN INTROSPECTIVA: SOROLLA}

La trascendencia que asumiera la obra de Rusińol en el desarrollo de la temática del jardín en la pintura española de inicios del siglo XX ha relegado a un plano secundario - de forma quizá algo injusta- la contribución de otros artistas plásticos que abordaron el motivo desde una perspectiva afín. Debido a sus contactos con alguno de los poetas más destacados del momento, resulta obligado detenerse ahora en la figura de Joaquín Sorolla (Valencia, 1863-Madrid, 1923), que gozó en la época de gran prestigio internacional gracias a sus celebérrimas escenas levantinas y a los luminosos lienzos de ambientación marina.

Por cuanto atañe al motivo del jardín, al igual que sucediera en el caso del modernista catalán, el descubrimiento de las ciudades de la Espańa meridional fue crucial para el pintor valenciano. Tras un breve periplo por Andalucía en 1902, Sorolla regresó a Sevilla en 1908 con el encargo de retratar a la reina Victoria Eugenia en los Reales Alcázares. El evocador marco de los antiguos jardines aparece ponderado en una carta del pintor a su esposa, datada el cuatro de febrero de aquel año: "Ahora cuando almuerce salgo para Palacio, pues quiero pintar en los jardines otro cuadro. Esto te gustaría, pues no pisas tierra nunca, todos están embaldosados con azulejos intercalados; las fuentes de azulejos, todo cercado de mirto, le dan una nota poética ${ }^{32}$. Poco después, el artista partía para Granada, donde habría de realizar entre 1909 y 1910 un importante conjunto de obras ligadas al entorno monumental de la Alhambra y los Jardines del Generalife. Lienzos como el titulado Jardín de los Adarves (fig. 6) reflejan bien la atmósfera melancólica y meditativa reconocible en esta etapa de madurez del pintor ${ }^{33}$. Los tonos sombríos y apagados del fondo establecen un marcado contraste con los pálidos senderos desiertos, que guían la vista del espectador y dotan la escena de suma profundidad.

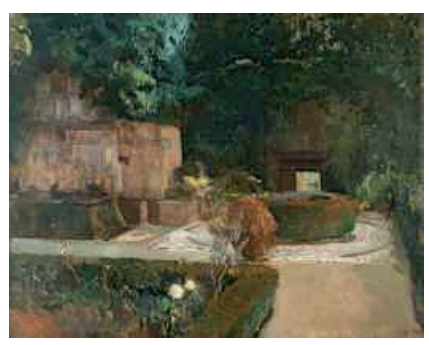

Fig. 6. Jardin de los Adarves. Alhambra, 1909-1910. Colección particular.

32. Joaquín Sorolla, Epistolarios de Joaquin Sorolla. Correspondencia con Clotilde García del Castillo (1891-1911), Blanca Pons-Sorolla y V. Lorente Sorolla (éd.), Barcelona, 2009, vol. III, p. 197.

33. Quisiera agradecer a doña Blanca Pons-Sorolla, principal estudiosa y biznieta del pintor, así como a don Jaime Gómez-Llera y don David Ruiz, asesor técnico del Museo Sorolla, la preciosa ayuda que me han brindado para facilitarme la reproducción de los lienzos que aquí se examinan. 
Una estructura muy similar puede apreciarse en otra obra algo más tardía, Fuente y jardin de la Alcazaba, Granada, que presenta asimismo el entorno nazarí envuelto en un ambiente solitario y melancólico.

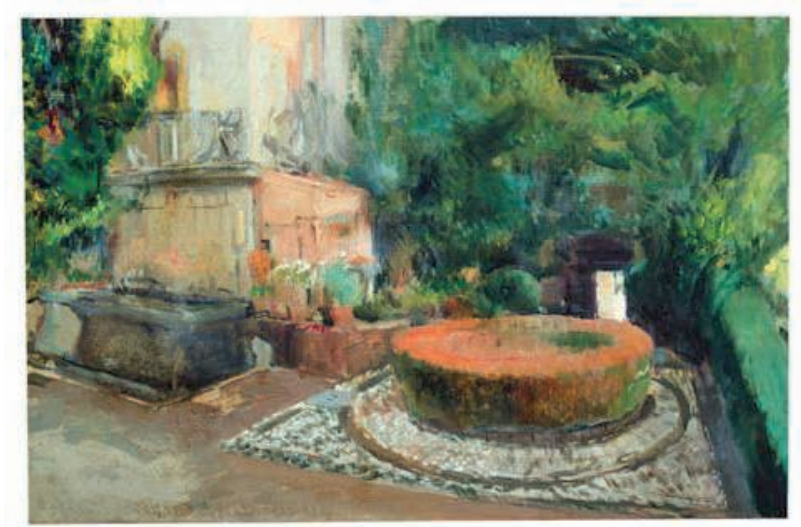

Fig. 7. Fuente y jardín de la Alcazaba (Granada), 1917.

A la hora de evaluar el ciclo de jardines sorollianos, en fechas recientes se ha subrayado cómo en este notable conjunto de lienzos de ambientación andaluza

La esencialidad y sobriedad de los patios de la Alhambra transmiten el fuerte carácter introspectivo de [su] obra madura. Los jardines del Alcázar de Sevilla y del Generalife de Granada insisten en esta tendencia a la melancolía. Sorolla los pinta como refugio al cansancio que le produce la vida social, a la que le obligan los encargos oficiales. Por eso, la figura humana está siempre ausente ${ }^{34}$.

Tal como podía apreciarse en la obra de Rusiñol, los jardines de Sorolla nacen marcados con una inequívoca pulsión elegíaca, que se sustenta en la observación de los elementos arquitectónicos erosionados, el brillo espejeante de las fuentes, los juegos de luz sobre la vegetación, presidido todo ello por una apremiante sensación de hastío ligada a la decadencia y el tiempo ${ }^{35}$. Uno de los lugares favoritos del pintor en el entorno nazarí es el Jardín de Lindaraja (figura 8), en cuya representación el artista juega a equilibrar la composición mediante la armonía de los distintos elementos verticales (el terno de estilizados cipreses) y circulares (la fuente y la diminuta plazuela en primer plano). El verde apagado y el gris mortecino dominan la gama cromática, creando una atmósfera de recogimiento y nostalgia.

34. María López Fernández, "Giardini», Sorolla. Giardini di luce, Ferrara, Ferrara Arte, 2012, pp. 147-150 (la cita se localiza en p. 147).

35. Jardines de España (1870-1936), Madrid, Fundación Mapfre, 1999. 


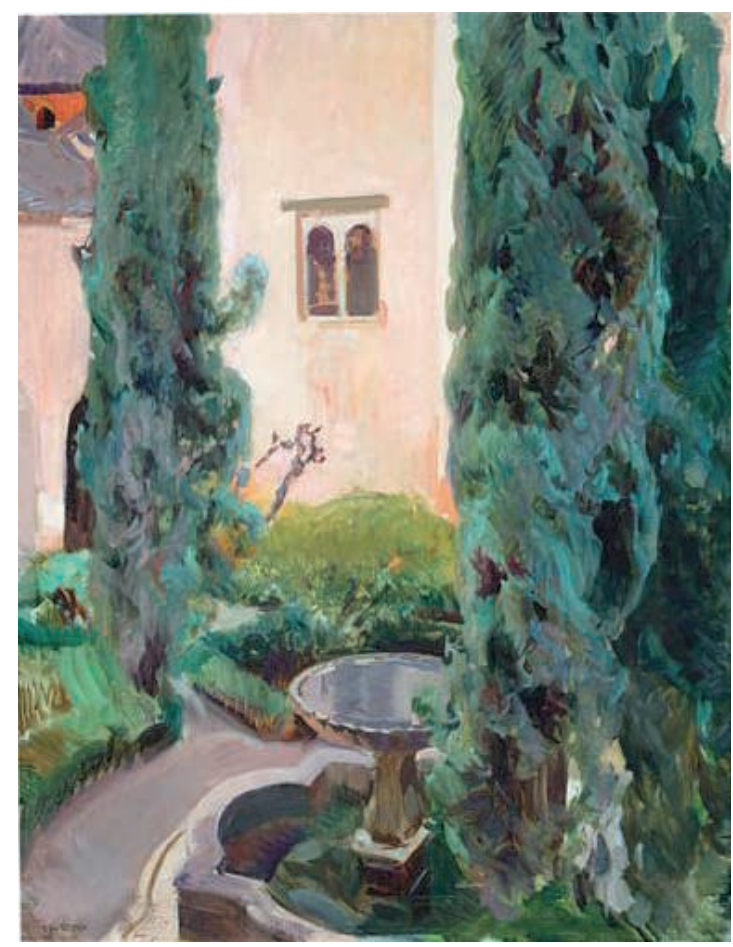

Fig. 8. El jardin de Lindaraja, la Alhambra (1910). Museo Sorolla.

Otra de las grandes revelaciones que Sorolla encuentra en los jardines andaluces es la melodía del agua, cuya fascinación reflejará en numerosos lienzos a través de estanques, fuentes y albercas. Algunas obras de la estancia sevillana incorporan de manera magistral el tema del reflejo, ligado a la necesidad de soledad y sosiego. En La alberca del Alcázar de Sevilla (figura 9), la presencia de un espejo de agua podría ligarse a la pasión simbolista por la imagen imprecisa y titubeante. La hilera de humildes macetas de flores aparece reproducida de forma pura y lineal sobre la tersa lámina de agua y apunta cómo la esencia de su hermosura radica precisamente en su desnuda sencillez ${ }^{36}$.

La experiencia de los jardines andaluces marcó a fuego las inclinaciones personales del pintor, quien al adquirir unos terrenos en el Paseo del Obelisco concibió el proyecto de trazar ante su casa-taller un espacio doméstico privado, siguiendo el modelo de los patios y jardines meridionales. La pintura de este ámbito personal e íntimo puede relacionarse con los denominados jardines de artista que pueblan la obra pictórica de autores tan diversos como Claude Monet (Giverny) y Max Liebermann (Wannsee) ${ }^{37}$.

36. María López Fernández, "Acqua», Sorolla. Giardini di luce, Ferrara, Ferrara Arte, 2012, p. 124.

37. Como señala Maria Cristina Tangorra, estableciendo un contacto entre ambos artistas europeos, «Max Liebermann compra nel 1909 un terreno sulle sponde del lago Wannsee e vi costruisce la sua casa. Intorno a quello che chiama il castello sul lago, si dedica con passione alla 


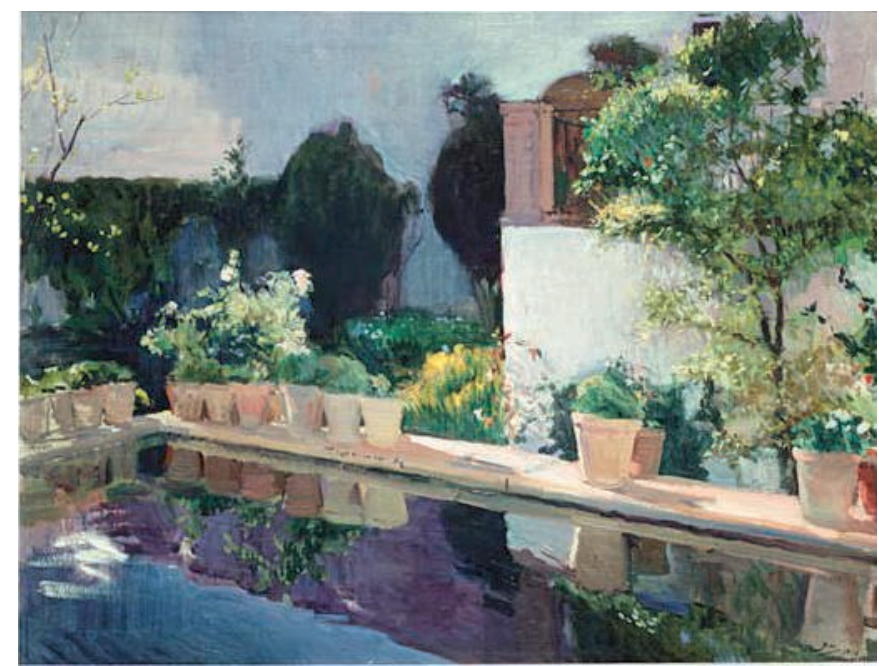

Fig. 9. Alberca del Alcázar de Sevilla, 1910. Museo Sorolla.

En el momento de establecer un contacto entre la obra sorolliana y los poetas del Modernismo el motivo del jardín proporciona una sugestiva clave de acceso. Por cuanto ahora nos atañe, en torno a 1902, debió de producirse el conocimiento entre Sorolla y Juan Ramón Jiménez, gracias al común amigo de ambos, el psiquiatra y neurólogo Luis Simarro (Roma, 1851-Madrid, 1921), en cuyo domicilio madrileño residió durante un tiempo el poeta. Poco después, la revista Alma española daba a conocer en su número de 1904 una semblanza de Juan Ramón Jiménez titulada «Sol de la tarde (pensando en el último cuadro de Joaquin Sorolla)». Con una prosa imbuida de matices poéticos, el escritor onubense evoca su reciente visita a la casa-taller del artista:

Tengo abierto mi balcón y el sol de esta tarde equívoca de invierno viene hasta mí, florido de luz cálida y primaveral, y me acaricia con dulzura finalmente, haciéndome sońar en islas lejanas y fragantes. El azul del cielo está nuevo y lujoso, favorable al ensueño juvenil. Y parece que tras ese palacio vecino que el sol sonrosa como en Abril, ha de lucir aquel mar tan distante [...]. Ayer he estado en el palacio de Joaquín Sorolla, que tiene un jardín con una fuente y después de buscar en el fondo de la fuente los ojos fijos de esa mujer, he llegado al estudio, en donde el pintor de Valencia guarda su tesoro de sol, arrancado a la tierra, y el rumor y la frescura azul y verde del mar; toda esa fiesta de naturaleza serena y honrada, que a mí me hace enmudecer y a veces sonreír. Cuando se entra en el estudio de Joaquín Sorolla, parece que se sale a la playa y al cielo; no es una puerta que se cierra tras nosotros; es una puerta que se abre al mediodía ${ }^{38}$.

creazione di un vasto giardino che diventa il soggetto preferito del suo lavoro. Ne risultano più di duecento tele in cui l'impressionismo si trasforma in una pittura sempre più marcatamente gestuale, sotto l'influsso dell'opera tarda di Monet». Il Giardino e la Pittura, Firenze, Angelo Pontecorboli Editore, 2011, p. 153-154.

38. Ángel Crespo reproduce el artículo como tercer elemento del Apéndice segundo («Escritos sobre arte no recogidos en libro») de la monografía Juan Ramón Jiménez y la pintura, Salamanca, Universidad de Salamanca, 1999, p. 214-218. 
Aquí, las citadas líneas no interesan tanto como primera confirmación del contacto personal entre ambos creadores, ni como valoración poética de la obra sorolliana en tanto reflejo de la luz y el calor del Mediterráneo, sino que se ligan a motivos vinculados simbólicamente a un mismo eje temático: «el sol de esta tarde equívoca de invierno", "he estado en el palacio de Joaquín Sorolla, que tiene un jardín con una fuente». La visita del poeta al pintor -planteada casi como un acto de "emotion recollected in tranquillity»- se asocia en el arranque de estas prosas líricas con la tarde, la luz invernal, el jardín y la fuente. El contacto y la estima personal que se estableció entre ambos creadores puede rastrearse asimismo a través de varios documentos de orden más personal. Por ejemplo, la importante biblioteca de la Casa Museo Sorolla custodia los ejemplares de las poesías con que el moguereño quiso obsequiar al admirado artista levantino. De hecho, uno de los primeros libros que debió de regalar a Sorolla, en 1904, fue precisamente Jardines lejanos. Durante la siguiente década, el contacto entre el pintor consagrado y el joven maestro de poesía debió de traducirse en un fluido intercambio epistolar y numerosas visitas a la casa taller. Algún vestigio de las mismas puede rastrearse en el epistolario de Jiménez, que solía encabezar sus misivas con este cariñoso encabezamiento: «Mi querido maestro»" ${ }^{39}$.

El testimonio definitivo de la admiración del poeta onubense por la maestría del pintor llegaría algunos años más tarde, en 1911-1912. El autor de Arias tristes elaboraba entonces una pequeña colección titulada Poemas impresionistas,

39. En el Archivo Histórico Nacional de Madrid (336/25 a 336/47) se conservan veinte tarjetas postales dirigidas a Juan Ramón, firmadas por el pintor y su familia. Entre las cartas redactadas por Jiménez entre 1898 y 1916, las misivas 153, 281 y 282 aparecen dirigidas a Sorolla. Sigo el texto de la reciente edición del Epistolario, Alfonso Alegre Heitzmann (éd.), Madrid, Publicaciones de la Residencia de Estudiantes, 2006, t. I, p. 222-223 y 388-389. Así, la carta que envía desde Moguer en 1909 permite ver cómo el escritor solicita la mediación del artista para la venta de un cuadro: «Queridísimo maestro: ahí va esa fotografía de un cuadro que existe aquí en Moguer. Quiero que me diga usted la opinión que forme sobre él y que, si hay oportunidad, hable de él a alguien que pueda o quiera comprarlo. Espero que este trabajo no le será enojoso en esas ciudades donde, según supongo, estará usted visitado por miles de personas inteligentes. Felicito a usted por esos enormes triunfos; y le deseo toda la salud que a mí me falta para seguir elevando su arte». (p. 222-223). Por otro lado, escritas ambas durante la primavera de 1913, en las otras misivas se puede apreciar cómo el escritor también servía como contacto a connaisseurs extranjeros que deseaban visitar al pintor: "Querido maestro: unos señores ingleses, amigos míos (y sumamente cultos), desean visitar el estudio de usted. Le agradeceré mucho que me ponga cuatro letras diciéndome qué día de esta semana y a qué hora podríamos ir» (p. 389). Algunas cartas a otros destinatarios indican asimismo cierta asiduidad, como la 299 (datada el 8 de noviembre de 1913): «Debo ir a acompañar a una comisión que entiende en el asunto del cuadro de Monforte, a casa de Sorolla» (p. 410). La relación de Jiménez con Sorolla debió de resultar, en ciertos aspectos, ambigua, como invitan a pensar los malévolos juicios que vierte en una carta del poeta a Luisa Grimm (datada en Moguer hacia 1908): «En cuanto a mis amigos del arte, escritores, pintores, músicos, filósofos [...] sólo cambio con ellos libros, impresiones y nada más. Usted conoce a dos de ellos; a Sorolla, un gran pintor, pero no lo saque usted de lo externo; no tiene la menor cultura ni quiere tenerla, con él no puedo hablar de nada, como no sea de sus cuadros; se casó con una mujer vulgar que ha matado, día tras día, una escasa semilla de ideal que empezó a germinar en su juventud, a juzgar por su obra de entonces» (p. 537). 
encabezada por la siguiente dedicatoria «A Joaquín Sorolla, mago de tonos e irisaciones». Por esas fechas, el pintor había realizado un viaje de estudios a la Andalucía occidental, ya que deseaba visitar el monasterio de la Rábida para componer un cuadro sobre Cristóbal Colón en el momento de emprender la travesía hacia las Indias. Durante su permanencia en la provincia de Huelva, Juan Ramón le acogió en su casa familiar. Así «en 1913 enseñaba a su devoto Juan Guerrero Ruiz un cuadro de Sorolla que representaba una casa de Moguer. El maestro levantino había estado en el pueblo de nuestro poeta y había ido con él a los pueblos cercanos, como Palos, que frecuentó cuando éste paró en su casa para cumplir un encargo de pintar a Colón saliendo» hacia las Indias ${ }^{40}$.

Junto al motivo melancólico aquí estudiado, otro puente de unión entre el mundillo literario y el pictórico está relacionado con el género del retrato que incorpora un fondo de jardines. Para ello debemos retrotraernos al año 1902, cuando el joven Jiménez viaja a Madrid para instalarse en la capital durante un tiempo. La estancia madrileña le brinda la ocasión de establecer contacto no sólo con los círculos más innovadores de la lírica del momento, sino también con los artistas plásticos de mayor renombre. «De todos los pintores de aquellos tiempos, Emilio Sala y Sorolla son los que merecen a Juan Ramón un juicio más favorable». Movido de una sincera admiración «sobre [el gran pintor valenciano] redactó algunos artículos entusiásticos» ${ }^{41}$. Entre los elogios que el escritor onubense brindó al artista cabe recordar el apunte titulado "Joaquín Sorolla y sus retratos». En su apreciación de esta faceta del creador levantino, Juan Ramón pondera el hallazgo en su pintura de «la verdad de las profundidades y de las sombras». Vincula además los variados retratos sorollanos a la maestría barroca de Rembrandt y Ribera y no duda en situarlos a la altura moderna y exquisita de Whistler ${ }^{42}$. Creemos que el interés del intelectual moguereño por este aspecto pictórico puede darnos algún indicio sobre los dos retratos que Sorolla hizo del poeta. Destaca en ambos lienzos la figura melancólica y seria del escritor, que sostiene un libro entre las manos. De modo significativo, al fondo de ambos lienzos se puede observar un ventanal, que se abre a la perspectiva vegetal de un jardín ${ }^{43}$. Desde el punto de vista estrictamente cronológico se antoja significativa la coincidencia temporal, ya que cuando Jiménez está a punto de publicar la colección de versos que titularía

40. Ángel Crespo, Juan Ramón Jiménez y la pintura, Salamanca, Universidad de Salamanca, 1999 , p. 45-46.

41. Ángel Crespo, Juan Ramón Jiménez y la pintura, Salamanca, Universidad de Salamanca, 1999, p. 181. Se recoge como apéndice III uno de los artículos sobre el gran pintor valenciano: "Sol de la tarde (Pensando en el último cuadro de Joaquin Sorolla)", pp. 214-218.

42. "Joaquín Sorolla y sus retratos», texto inédito recogido en Juan Ramón Jiménez y la pintura, Salamanca, Universidad de Salamanca, 1999, p. 196-198.

43. Puede recordarse cómo en Arias tristes y Jardines lejanos asume una importancia capital el poema concebido desde un «marco» visual específico: la contemplación de un paisaje exterior a través de una ventana o un balcón. Ha dedicado importantes reflexiones a este asunto Luis Iglesias Feijoo: «Función del marco en la poesía del primer Juan Ramón», Congreso Internacional Conmemorativo del centenario de Juan Ramón Jiménez, Huelva, Diputación de Huelva, 1983, vol. II, p. 365-377. 
Jardines lejanos, en un momento impreciso hacia 1904, Sorolla lleva a cabo su primer retrato del poeta, con fondo de jardín (fig. 10). No sería la última vez que el esteta andaluz posara ante el maestro: casi quince años más tarde, en 1916, Joaquín Sorolla volvía a retratar al poeta, aureolado ya con una fama internacional (fig. 11).

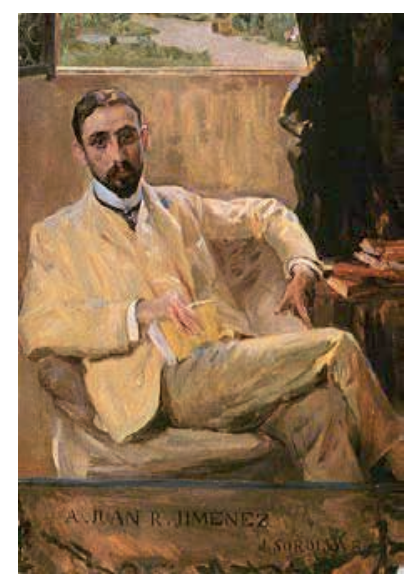

Fig. 10. Joaquín Sorolla, Retrato de Juan Ramón Jiménez. Óleo sobre lienzo.

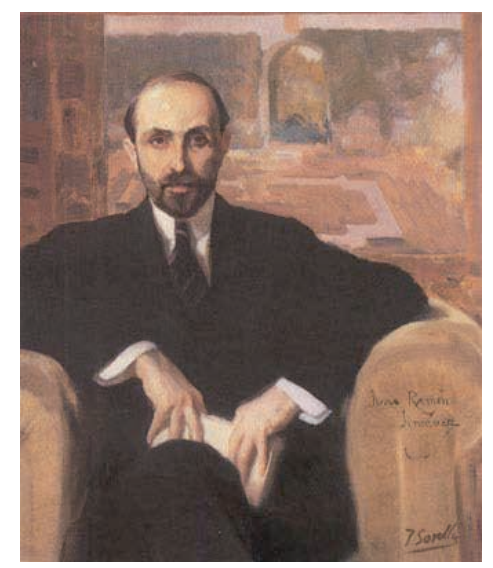

Fig. 11. Joaquín Sorolla, Retrato de Juan Ramón Jiménez. Óleo sobre lienzo (Hispanic Society of America).

El aire fuertemente introspectivo de ambos lienzos revela los cambios físicos del escritor. La segunda imagen, deja ver una incipiente calvicie; la perilla de signo dannunziano ha dado paso ahora a una seria, circunspecta y poblada barba. El toque algo dandístico del traje juvenil de colores claros ha quedado atrás, remplazado por la severa estampa de un elegante dos piezas oscuro. Sin embargo, más allá de los signos que evidencian el paso del tiempo y el rigor ascético del hombre maduro, más allá de los elementos de la indumentaria, de nuevo, un elemento latente conecta ambos lienzos, ya que Sorolla seguirá prestando suma atención al motivo simbólico que le sirve de fondo: el jardín. Las dos imágenes parecen insistir en la identificación del moguereño universal como un meláncolico escritor de jardines. Sin embargo, podría casi hablarse de un sutil trompe l'oeil, ya que el fondo de la imagen de 1916 -encargada por Archer Milton Huntington para la Hispanic Society- no debe identificarse con un ventana abierta. Como si de un efecto de ilusionismo se tratara, el jardín que puede contemplarse a espaldas del poeta no es un jardín real, sino un conocido lienzo de Sorolla, pintado entre enero y febrero de 1910 (Fuente y patio del Alcázar de Sevilla). El diálogo que se establece así entre jardín y retrato, entre poesía y visión, entre ensueño y artes visuales plantea algunas preguntas, como ha subrayado en fechas recientes Tomás Lloréns: 
che riguarda l'essenza nuda, ultima, della poesia e della pittura. Ed entrambi fantasticano sull'immagine del giardino chiuso, intriso di luce, immerso nel silenzio ${ }^{44}$.

La conexión entre el pintor levantino y el escritor onubense a través del jardín no se agota en los aspectos ya estudiados. En efecto, gracias a la mediación de Juan Ramón Jiménez y Joaquín Sorolla, la Junta de Ampliación de Estudios concedió a Javier de Winthuysen una pensión de estudios que le permitiera rastrear el origen de los jardines espańoles y la singularidad que los caracteriza. El citado estudioso documentó un importante conjunto de jardines históricos (algunos en estado de parcial abandono) y acumuló un importante material fotográfico sobre los mismos. Tras una investigación meticulosa, en 1930 Winthuysen daba a las prensas el ensayo español más importante sobre el Ars topiaria: los Jardines clásicos de España. Como pequeña prenda de gratitud, la obra estaba dedicada «Al poeta Juan Ramón Jiménez y a la memoria del pintor Sorolla». Este monumental tratado, en el que se aúnan erudición y sensibilidad, de alguna manera suponía un radiante epílogo para la icónica alianza entre la pintura y la poesía encarnadas en el motivo del jardín.

\section{Oro y Rosa: LOS JARDines múltiples de JuAN Ramón JimÉNEZ}

Por motivos bien justificados, en el ámbito de las artes del fin de siglo se ha concedido a Rusiñol el magisterio de un dominio simbolista como el jardín abandonado. Al pasar al terreno estrictamente literario, más allá de las prosas líricas rusiñolianas (Impresiones de arte) y su poema en prosa (An el jardins abandonats), el escritor que desarrolló con mayor denuedo el motivo del jardín en el panorama lírico modernista fue Juan Ramón Jiménez (Moguer, 1881-San Juan de Puerto Rico, 1958 $)^{45}$. Mediante el examen de algunas composiciones de Rimas (1900-1902), Arias tristes (1903), Jardines lejanos (1904) y Hojas verdes (1906) trataremos de indagar en la forma y sentido de uno de los núcleos temáticos más destacados en su obra de juventud ${ }^{46}$. Por otro lado, para comprender la afinidad que ostentan los jardines juanramonianos con la pintura del momento, conviene recordar cómo la pasión del moguereño por las artes plásticas surgía de una vivencia muy personal: entre 1896 y 1900 el joven aspirante a artista se instaló en Sevilla para formarse como pintor en el estudio del maestro gaditano Salvador Clemente y también recibió clases del

44. «Giardini ultimi», Sorolla. Giardini di luce, Ferrara, Ferrara Arte, 2012, p. 39-49 (la cita en p. 49).

45. Antonio Pau Pedrón, Juan Ramón Jiménez, el poeta en el jardín, Madrid, Trotta, 1999.

46. En una carta escrita desde Moguer a Gregorio Martínez Sierra -datada en agosto de 1907- el propio escritor reconocía la existencia de cierta unidad de tono entre varios de sus volúmenes iniciales: «Debo decir que Olvidanzas está casi terminado y que las Baladas y las Elegías me tienen contento [...]. Mi gusto sería dar todos estos libros juntos, porque Pastorales se parece a Arias tristes y a Jardines lejanos». Tomo la cita de la reciente edición del Epistolario, Alfonso Alegre Heitzmann (éd.), Madrid, Publicaciones de la Residencia de Estudiantes, 2006, t. I, p. 186. 
artista francés Léon Bonnat ${ }^{47}$. La inclinación a las letras fue ganando terreno a la vocación pictórica inicial, aunque ésta no dejó de manifestarse durante toda su trayectoria poética posterior gracias a un tipo de escritura imbuida de valores plásticos.

En el primerizo libro de las Rimas puede rastrearse la presencia del motivo a lo largo de varios poemas, como el XIV (El palacio viejo), el XVIII, el XLV (Exótica), el LI (Paisaje) o el LXI (Vaga) ${ }^{48}$. En alguno de estos textos aparecen subrayadas las claves del abandono y la decadencia, así se reconocen en el XIV: «El jardín ha enlazado la arboleda frondosa / de sus calles sombrías. En el lago, las piedras / de algún puente han caído carcomidas; el musgo / ha cubierto las fuentes. Una onda serena / de quietud baña todo. / No es terror, no es tristeza /esa sombra que vaga; / es la amarga hermosura de lo viejo, la esencia / que en el mundo dejaron otras flores, la música / de otras liras, la ronda de las áureas bellezas / que se van; es la vida que respira la muerte, es la luz de la niebla $»^{49}$. A los ecos perceptibles del magisterio rusiñoliano se suman las vagas reminiscencias de Verlaine, como en la composición XVIII: «Me he asomado por la verja / del viejo parque desierto: / todo parece sumido / en un nostálgico sueño. / Sobre la oscura arboleda, / en el transparente cielo / de la tarde, tiembla y brilla / un diamantino lucero [...]. / Mis ojos pierdo, soñando, / en la bruma del sendero; / una flor que se moría / ya se ha quedado sin pétalos [...] / El jardín vuelve a sumirse / en melancólico sueño / y un ruiseñor dulcemente / gime en el hondo silencio» ${ }^{50}$. Desde el punto de vista de la conexión con un tipo de enfoque plástico cobran gran importancia los versos dedicados al médico Luis Simarro, ya que Paisaje se asemeja -con su juego de tintas vagas, luces y sombras- al espacio recogido e íntimo de los lienzos de Rusiñol:

\footnotetext{
Hacia Oriente, las gasas del moribundo día funden jardín y cielo con la dulce armonía de sus vagos matices: sobre un cielo violeta destiñe sus verdores el jardín. En la quieta placidez del conjunto no hay golpe vigoroso ni alegre que distraiga; es éste un religioso desleimiento de tonos delicados; las lilas, que están en flor, aúnan sus dulzuras tranquilas con la lejana fronda. Nada turba la calma de calor... ¡Ah! No sé si subirá algún alma por esas suavidades... Una larga avenida huye al regazo lóbrego de la selva dormida, y la linfa, rendida de sueño y de penumbra, del lago azul profundo, tenuemente relumbra
}

47. Rocío Fernández Berrocal, "Juan Ramón Jiménez: pintor y poeta en Sevilla», Turia. Revista Cultural, 77-78, 2006, p. 278-281.

48. Rimas (1900-1902), Javier Blasco (éd.), Madrid, Visor-Diputación de Huelva, 2006. José Antonio Expósito Hernández, «Nuevos descubrimientos sobre Rimas, Arias tristes y Jardines lejanos de Juan Ramón Jiménez», Ínsula, 720, 2006, p. 8-10.

49. Rimas (1900-1902), Javier Blasco (éd.), Madrid, Visor-Diputación de Huelva, 2006, p. 54-55.

50. Ibidem, p. 61. 
tras la fronda entreabierta. Todo va en un descenso de forma y de matiz; todo pierde el intenso vigor que el sol da a todo, cuando con luz lo agranda (¿es que la tarde quita lo que la aurora manda?) [...].

Entre mis ideales

miro cómo agonizan estos primaverales

crepúsculos; yo siento sus dulces agonías porque mueren sus lumbres como mueren las mías. Todo tiembla. La luz va extinguiéndose lenta; en mi alma va cayendo la sombra sońolienta [...].

La agonía de la luz crepuscular sirve de reflejo a la sensación de finitud del propio yo lírico. Por otro lado, el poema acoge una serie de referentes léxicos ligados al ámbito de la imagen pictórica: «matices», «destińe», "desleimiento», «forma y matiz», «luz», «penumbra».

Al igual que sucede en el volumen de las Rimas, el conjunto de poemas titulado Arias tristes incorpora un significativo ciclo de textos que giran en torno al motivo del jardín (V, IX, XV, XVII). Todos ellos se agruparían, significativamente, en la sección inicial del libro, rubricada como Arias otoñales. Este primer apartado aparecía, además, encabezado por una partitura de Schubert (Elogio de las lágrimas), acompañada por la anotación "Muy lentamente». El poema $\mathrm{V}$ ofrece la visión del jardín autumnal desde una ventana:

El cielo gris y violeta
de la tarde fría, daba
no sé qué ensueño al jardín
sin amor y sin fragancia.
Yo miré por los cristales
y las sendas solitarias
y la fuente seca, todo
era más triste que el alma.

\author{
Por el cortinaje antiguo \\ el crepúsculo filtraba \\ una luz de niebla y sueño, \\ acariciadora y lánguida; \\ y entre la tristeza que \\ la tarde daba a la estancia, \\ bruma, encanto, ronda suave \\ de cadencias y nostalgias $[\ldots]^{51}$.
}

El encuadre del poema (la visión del jardín desde una ventana) resulta muy propio de la primera etapa juanramoniana, como magistralmente estudiara Luis Iglesias Feijoo ${ }^{52}$. Los citados octosílabos reflejan el tono flébil y lánguido de una cierta corriente simbolista, poblada por la «niebla» y el «sueño», por la «bruma» y las «nostalgias». El conjunto de calificativos que definen los elementos contemplados (el cielo, la tarde, las sendas, la fuente, los cortinajes...) permite acotar un espacio opresivo y enfermizo ("gris», «fría», «solitarias», «seca», "triste», «antiguo»). La tristeza indefinida y vaga del yo lírico observa ensimismada su reflejo en el espacio que le circunda.

Otras veces, el motivo da paso a una evocación melodramática, como en el poema IX, donde el locutor poético se recrea de forma mórbida en la evocación

51. Arias tristes (1903), Carmen Morán Rodríguez (éd.), Madrid, Visor-Diputación de Huelva, 2010, p. 42.

52. «Función del marco en la poesía del primer Juan Ramón», Congreso Internacional Conmemorativo del centenario de Juan Ramón Jiménez, Huelva, Diputación de Huelva, 1983, vol. II, p. 365-377. 
de su propia muerte, contrastando su ausencia con la añoranza que el jardín siente por su propietario:

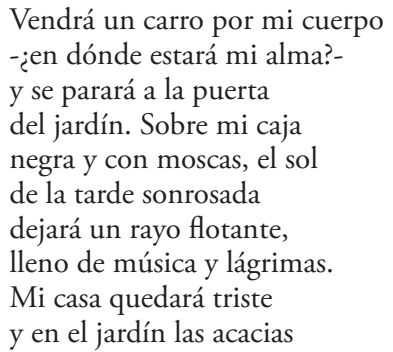

Vendrá un carro por mi cuerpo

que quise tanto, mis pobres acacias finas y lánguidas, esperarán que mi mano se alce para acariciarlas y mi mano estará fría bajo la tierra; y el agua de la fuente, en el silencio de la fronda abandonada, llorará, llorará muerta de tristeza y de nostalgia $[\ldots]^{53}$.

El arranque efectista de la composición (con el negro féretro que espera acoger el cadáver del locutor poético ante la cancela del jardín) marca una obertura fúnebre, como una mancha de corrupción que se extiende sobre el paisaje. Las acacias abandonadas, la vegetación que no acaricia la mano del hombre y el agua estancada y pútrida se erigen -a zaga del antiguo dueño que yace bajo tierra- en signos de la muerte que impera. Desde el punto de vista de la pragmática de la enunciación lírica, el escritor recurre aquí a una figura tan marcada como la idolopeya, produciéndose un «desplazamiento de la voz» hacia el futuro para articular una "representación de la propia muerte» ${ }^{54}$.

La atmósfera enfermiza y opresiva del otońo irrumpe obsesivamente en estas composiciones octosilábicas ligadas, como muestra el poema XV, donde el espíritu decaído del yo lírico establece una alianza fraterna con el espacio ajado y gris del jardín:

\author{
Mi alma es hermana del cielo \\ gris y de las hojas secas; \\ sol enfermo del otońo, \\ ¡mátame con tu tristeza! \\ Los árboles del jardín \\ están cargados de niebla: \\ mi corazón busca en ellos \\ esa novia que no encuentra; \\ y en el suelo frío y húmedo \\ me esperan las hojas secas: \\ ¡si mi alma fuera una hoja \\ y se perdiera entre ellas! \\ El sol ha mandado un rayo \\ de oro viejo a la arboleda,
}

\author{
un rayo flotante, dulce \\ luz para las cosas muertas. \\ ¡Qué ternura tiene el pobre \\ sol para las hojas secas! \\ Una tristeza infinita \\ vaga por todas las sendas, \\ lenta, antigua sinfonía \\ de músicas y de esencias, \\ algo que dora el jardín \\ de ensueño de primavera. \\ Y esa luz de ensueño y oro \\ que muere en las hojas secas \\ alumbra en mi corazón \\ no sé qué vagas tristezas 55 .
}

El inicio melancólico de la composición, que identifica el espíritu del locutor poético con un elemento externo, recuerda vagamente el célebre comienzo del primer poema del volumen $A u$ jardin de l'Infante: "Mon âme est une infante

53. Arias tristes, ed. cit., p. 51.

54. Ángel Luis Luján Atienza, «Yo me moriré y la noche... Enunciación e idolopeya en Arias tristes", Dicenda, 20, 2002, p. 213-228 (p. 222).

55. Arias tristes, p. 63-64. 
en robe de parade, / dont l'éxil se reflète, éternel et royal, / aux grands miroirs déserts d'un vieil Escurial, / ainsi qu'une galère oubliée en la rade» ${ }^{56}$. Más allá de las tenues reminiscencias samainianas, parece oportuno indicar cómo uno de los principales elementos icónicos del poema («las hojas secas» ${ }^{57}$ ) podría relacionarse con el modelo de la Chanson d'automne de Verlaine, cuyo cierre incorpora un símil en el que el yo lírico se asemeja a una hoja muerta arrastrada por el protervo viento del otońo: «Et je m'en vais / au vent mauvais / qui m'emporte / deçà, delà, / pareil à la / feuille morte " ${ }^{58}$. El volumen de Arias tristes recoge aún otro testimonio, bello y doliente, de los jardines melancólicos juanramonianos (el de la composición XVII):

Jardín de otońo, con mármoles
de elegía. Lago lleno
de hojas secas y de sol
melancólico y enfermo.
Entre la fronda amarilla
aparece y brilla el cielo
dorado, de un oro blanco,
de un oro pálido y muerto.
Y bajo la quieta linfa
verdinegra, flota un sueño
de sol, un sueño de oro,
un sueño de troncos secos.
He pasado por la senda [...].
Y me he internado en el triste
jardín. Abro el libro y leo...
El sol me dora la página
y envuelve en lumbre los versos ${ }^{59}$.

Con el pequeño conjunto de textos procedentes de las Rimas y las Arias tristes aquí examinados podrían ya trazarse las coordenadas principales de los juveniles jardines juanramonianos: el otoño, el crepúsculo, la melancolía, la ensoñación, la muerte, la añoranza, la luz dorada y pálida, las aguas estancadas y silentes, las sendas solitarias, la tristeza indefinida, la ausencia del amor, el anuncio del final inminente, la música, el aroma de la decadencia... En definitiva, nos hallamos ante una de las muestras más brillantes de la poética del jardín finisecular, acuñada magistralmente por Verlaine y Samain, así como por Rusiñol, en la página y en el lienzo ${ }^{60}$. Con todo, estos primeros ensayos juveniles no debieron

56. Au jardin de l'Infante, Paris, Mercure de France, 1911, p. 11.

57. Como aproximación general puede verse el estudio de Luisa Fernanda Rodríguez Lara, «La hoja: signo poético en Juan Ramón Jiménez», Cauce, 4, 1981, p. 151-163.

58. Fêtes galantes. Romances sans paroles, Paris, Gallimard, 2007, p. 58.

59. Arias tristes, p. 67.

60. Puede consultarse una aproximación muy general al tema: María Alejandra Zanetta, «El jardín abandonado en la primera poesía de Juan Ramón Jiménez y en la pintura de Santiago Rusiñol: un análisis comparado", Ínsula, 625-626, 1999, pp. 37-40. Disiento, empero, de algunas afirmaciones allí vertidas, como «los jardines son lugares ideales en donde ambos artistas pretenden burlar la muerte, reflejando en su obra el poder de renovación constante de la naturaleza» (p. 38). A tenor de las imágenes y los textos examinados, se antoja poco acertado 
de satisfacer por completo las exigencias del refinado esteta onubense, ya que aún trató de explotar los variados perfiles del motivo dedicándole nada menos que un entero libro de poemas: Jardines lejanos $(1904)^{61}$.

En un interesante apunte sobre la joven poesía española de inicios del Novecientos, publicado en La Revue en 1906, la veterana novelista Emilia Pardo Bazán definía el conjunto de los Jardines lejanos mediante una sugestiva imagen: «des tableautins d'un charme elégiaque»" ${ }^{62}$. A la hora de establecer una valoración de los sentidos del jardín juanramoniano a través de estos "pequeños cuadros» adornados de un suave "encanto elegíaco» puede abrirse la reflexión con el examen del segundo poema de la sección inicial (Jardines galantes):

Hay un oro dulce y triste en el malva de la tarde, que da realeza a la bella suntuosidad de los parques.

Y bajo el malva y el oro se han recogido los árboles verdes, rosados y verdes de brotes primaverales.

En el cáliz de la fuente solloza el agua fragante, agua de música y lágrima, nacida bajo la hierba entre rosas y cristales...
Sólo había que esperar a los luceros; la carne se hacía incienso y penumbra por las sendas de rosales...

Y, de repente, una voz melancólica y distante, ha temblado sobre el agua en el silencio del aire.

Es una voz de mujer y de piano, es un suave bienestar para las rosas soñolientas de la tarde;

sostener que Rusińol y Jiménez pretenden con sus jardines «burlar la muerte». Según los parámetros de la estética simbolista y decadente, puede intuirse más bien que ambos creadores exaltan la hermosura de una bella agonía, la nobleza serena de una muerte melancólica y digna. En mi modesta opinión, no se trataría tanto de «burlar la muerte», sino de exaltar un final imbuido de un valor estético, a la manera de un Triunfo de la Muerte.

61. La cuidada estructura de esta obra poética y uno de sus temas vertebradores (la presencia del agua) ha sido objeto en fechas recientes de una iluminadora indagación de Juan Varo: «El tema del agua en Jardines lejanos de Juan Ramón Jiménez», Salina. Revista de Lletres, 22, 2008, pp. 123-130. El profesor granadino presenta así el entero volumen: «Jardines lejanos estaba dividido en tres secciones cuidadosamente dispuestas, tituladas "Jardines galantes», "Jardines místicos» $\mathrm{y}$ "Jardines dolientes». Las dos primeras secciones configuran un complejo abanico de motivos que avanzan hacia su resolución dialéctica en la tercera parte, "Jardines dolientes». Así si en la primera parte el erotismo jovial, la sensualidad de los colores brillantes, las rosas rojas y la alegría de la carne, con el recuerdo de sus experiencias en Francia de fondo, abocan a un agudo sentimiento de culpa; en la segunda, "Jardines místicos», el impulso deviene negativo, caracterizándose por la renuncia y el conocimiento profundo, simbólico, de esa realidad sentimental que se alza más allá de los sentidos. El espacio se vuelve frío, espectral; frente a la poesía solar de la primera sección, esta segunda se inclina por los paisajes lunares. Y se asiste a un proceso paulatino de des-realización del «yo», otro de los temas cruciales de este libro. La tercera sección, "Jardines dolientes», se recrea en los atardeceres de colores suaves. El poeta prefiere ahora los jardines enfermos, sin flores y con hojas secas. «Es el espacio de la nostalgia, de la exaltación decadentista de la enfermedad y el dolor como único estado de ánimo en el que es posible agudizar las capacidades de la percepción y del conocimiento» (p. 123).

62. "Le mouvement littéraire en Espagne. Les poètes espagnols du $\mathrm{XX}^{\mathrm{e}}$ siècle», Obras completas, Harry L. Kirby (ed.), Madrid, Aguilar, 1973, t. III, p. 1274-1281 (p. 1276). 
...Ya el corazón se olvidaba de la vida...; por los parques todo era cosa de ensueńo, luz de estrellas, alas de ángeles... una voz que me va haciendo llorar por nadie y por alguien en esta triste y dorada suntuosidad de los parques ${ }^{63}$.

Este breve romance lírico presenta una imagen ya vista en otros autores: un parque solitario iluminado por los arreboles dorados y malvas del crepúsculo. Destaca en la composición el empleo de la estructura circular, que enlaza la primera cuarteta con los dos octosílabos finales: «Hay un oro dulce y triste / en el malva de la tarde / que da realeza a la bella / suntuosidad de los parques» - «en esta triste y dorada / suntuosidad de los parques». Este artificio compositivo de matriz estática y descriptiva, de hecho, recurre con inusitada frecuencia en todo el libro, como revelan los poemas I, VI, XV, XVIII, XIX, XXII, XXVI y XXVII de Jardines galantes; los textos III, IX, X y XI de Jardines misticos, así como los poemas IX, XII, XX, XXI, XXII, XXIII y XXIV de los Jardines dolientes ${ }^{64}$. El

63. Jardines lejanos, Madrid, Visor-Diputación de Huelva, 2007, p. 30-31.

64. «Esta noche, los jardines / tienen plata y seda, en una / luz de fiesta; los violines / se han prendado de la luna» - «Hubo rostros amarillos / por la sombra del jardín... / Solo, a la luna, un violín / lloraba sus estribillos / en la fiesta del jardín» (p. 27-29). "No hay sol; el cielo de invierno / es de bruma y nubes blancas; / sólo hay un raso celeste / sobre las araucarias» - «Pero el cielo gris ha puesto / muy rosas todas las almas / y tiende rasos celestes / sobre las araucarias» (p. 40-41). «Está naciendo la luna / sobre el río y está rosa / entre los árboles de oro / de la tarde melancólica. / Crepúsculo triste, con / estrellas verdes...» - «La ribera está encantada... / y la luna sube rosa / sobre los árboles mustios / de la tarde melancólica» (p. 58-59). «Tarde en gris y plata, tarde / violetamente nostálgica, / tarde de paseos lánguidos / bajo las verdes acacias» - «que las sendas sepan cómo / después resbalan las lágrimas... / Y la tarde es plata y es / violetamente romántica» (p. 64-65). «Sus ojos eran azules, / de azul de glicinas, pero / yo nunca pude saber / si eran rubios sus cabellos...» - «Hablaba siempre en azul, / era dulcísima... pero / yo nunca pude saber / si eran rubios sus cabellos» (p. 66-67). «Viene, en la noche de junio, / bajo una voz que desgarra, / el llanto de una guitarra / prendada del plenilunio» - «Llanto de hombre, que desgarra / entre la noche de junio, / a la luz del plenilunio / que hace hablar a la guitarra» (p. 7475). «Luna de oro, velada / tras esas nubes en flor, / ¿a qué te pones dorada / sobre el jardín sin amor» - «Luna de oro, velada / tras esas nubes en flor, / ¡a qué te pones dorada / sobre el jardín sin amor» (pp. 83-85). «A lo azul, en los jardines / llenos de faroles rojos / los valses de los violines / nublan de llanto los ojos» - «Pasa el aire... Y los violines / que ponen ciegos los ojos / lloran más, en los jardines / llenos de faroles rojos» (p. 86-87). «A la lumbre de la luna / -sueño de rosa y de plata- / corazón, preludia una / romántica serenata» - «A la lumbre de la luna / -sueńo de rosa y de plata- / corazón, preludia una / romántica serenata» (p. 103-104). «En la tarde suave y lenta / -muerta en paz, sin fuegos rojos- / una estrella sońolienta / llora enfrente de mis ojos» - «En la tarde suave y lenta / -muerta en paz, sin fuegos rojos- / una estrella sońolienta / llora enfrente de mis ojos» (p. 118-119). «Hay un balcón entreabierto; / tiene una luz amarilla; / aunque nadie llora, se oye / llorar... La noche es tibia... / La noche está tibia y llena / de flores y de caricias» - «Hay un balcón entreabierto; / es una luz amarilla... / La noche está tibia y llena / de flores y de caricias...» (p. 120-121). «Mira, el jardín teje plata / con seda de rosas. ¿¿Sientes / la dulce mandolinata / del corazón de las fuentes?» - «Mira el jardín teje plata / con seda de olvido. ¿Sientes / la dulce mandolinata / del corazón de las fuentes? (p. 122-123). «Como la tarde ha caído / he entreabierto mi ventana... / ¡Tarde novia, tarde hermana, / tarde de color de olvido!» - «Mientras mueres, he venido / a llorar en mi ventana, / ¡tarde novia, tarde hermana, / tarde de color de olvido!» (p. 189-190). "Vamos los dos a olvidarnos... / no sirven nuestros amores. / Mira, vamos a arrancarnos / del corazón nuestras flores» - «El sol nos dará su lumbre, 
examen de las composiciones en anillo dentro del poemario permite ver la sutil variación en torno a distintas modalidades que emplea el poeta de Moguer, así como la "preferencia generalizada de vincular el procedimiento a paisajes otoñales y crepusculares» ${ }^{65}$. La estructura de reiteración circular que define un notable conjunto de las composiciones de este libro poético incide en uno de sus rasgos más llamativos, el establecimiento de una entonación monocorde, hasta el extremo que el poeta y crítico Luis Antonio de Villena ha afirmado sobre el mismo que «el libro es largo y desde [nuestro] hoy podríamos decir que algo monótono en el opresivo tema del jardín triste, de las novias o amadas enfermas, lánguidas o imposibles, en medio de la bruma, el decaimiento, la nostalgia, el otoño, la suave desesperación de un alma que busca y que sólo halla languidez, angustia, vacío, ansias de renovación, en una palabra, el retrato de un espíritu decadente» ${ }^{66}$.

El espacio melancólico y lánguido del gran jardín solitario está poblado de una indefinida tristeza, que desrealiza la escena y la puebla de matices oníricos: «solloza el agua fragante, / agua de música y lágrima», "todo era cosa de ensueño», «el silencio del aire». Desde el arranque mismo del poema se aprecian los efectos que sutilmente crea la sinestesia («oro dulce y triste»). De hecho, este tipo de intercambios sensoriales pueden hallarse en varios pasajes significativos a lo largo del entero volumen: "Tú te acuerdas [...] de aquel son / suave y blanco de Beethoven»; "viene un cándido olon»; «el alma misma no sabe / si esta claridad süave / es de novia o de azucena»; «en la calma oliente y negra / suena un agrio cornetín»... ${ }^{67}$. Creo que la relevancia de la sinestesia en los Jardines lejanos proporciona una pequeña clave acerca del libro poético, ya que por aquellas fechas la crítica tradicionalista había censurado acremente el empleo de esta figura por parte de los jóvenes escritores adscritos al Modernismo. Baste recordar el anatema que Antonio de Valbuena había lanzado ya en 1896 sobre tal detalle:

/ la tierra en flor sus amores / y... yo no sé... por costumbre / arrancaremos las flores» (p. 196197). «¡Otoño gris y amarillo! / ¡Ay! ¡Otoño de mi alma! / ¡Me vas mostrando tus tardes / y yo no quiero mirarlas!» - «iOtońo, otoño! Y yo pude / tenerla... Y no tengo nada... / ¿a qué me enseñas tus tardes / si yo no quiero mirarlas?» (p. 213-214). «Ella respondió llorando: / no sé por qué me la pides... / tu olvido me está matando; / ¿̇te he dicho que no me olvides?» - «Bien sé que me estás matando; / ¿te he dicho que no me olvides? / Pero ellas están llorando... / no sé por qué me las pides» (p. 215-216). «Las últimas flores rosas / parece que no se duelen, / hay como una primavera / de celestillas celestes» - «Las últimas flores rosas / parece que no se duelen, / hay como una primavera / de celestillas celestes» (p. 217-219). «Cuando el corazón nos duele / por causa de una mujer, / ¡qué dulce es poder tener / un jardín que nos consuele» - «QQué dulce es poder tener / un jardín que nos consuele, / cuando el corazón nos duele / por causa de una mujer» (p. 220-221). "Tarde doliente de almas. / Los lloradores de rosas / han salido a ver si encuentran / por los parques a sus novias» - «Llueve. Otoño, niebla, sueño... / Los lloradores de rosas / han salido a ver si encuentran / por los parques a sus novias» (p. 222-223).

65. Ángel Luis Luján Atienza, «La estructura circular en la poesía post-romántica y el Modernismo. Avatares en la creación del sentido poético", Iberoromania, 60, 2004, p. 59-81 (la cita en p. 77).

66. Prólogo a Jardines lejanos, ed. cit., p. 10.

67. Ed. cit., p. 84, 100, 109 y 134. 
Enamorados los decadentes de ciertas combinaciones de palabras sonoras, o empleando su propia frase, de la instrumentación poética, a esta sacrifican las ideas, los pensamientos, la lógica, la gramática, todo, absolutamente todo. La combinación nueva de palabras, el emplearlas en sentido en que nadie las haya empleado nunca, el decir las cosas al revés, como nadie las haya dicho es su afán constante. Tienen por sistema cambiar la naturaleza de las cosas y el oficio de los sentidos y así hablan a lo mejor de un sonido azul, de un aroma verde, de un color sabroso o aromático ${ }^{68}$.

Junto a la sinestesia, en los jardines juanramonianos confluyen asimismo elementos de naturaleza artística. Por ejemplo, la composición XVIII de los Jardines misticos aparece identificada con un sugestivo título Jardín de Museo, recalcando acaso la importancia que en ella asumen los elementos arquitectónicos y escultóricos que identifican su espacio:

\author{
Bajo la serenidad \\ del cielo de primavera \\ tiene sus grises al sol \\ de oro, la piedra vieja... \\ El jardín está ya verde, \\ las penumbras son violetas, \\ frente a los pechos de mármol \\ se entreabren las rosas nuevas. \\ Diana caza bajo el pórtico, \\ hay una fuente que sueña, \\ los pájaros nuevos cantan \\ sobre la clásica piedra...
}

... El sol de la tarde dora
los rosales y las hierbas,
los blancos pechos de mármol,
los ojos ciegos... y lleva
por la senda una dulzura
tan triste, que los poetas
echan a llorar sus ojos
bajo el pórtico de piedra.
Corazón, pues que la muerte
tińe de oro tu belleza,
dile la última elegía
de mayo a la primavera

La paleta empleada aquí por el onubense se centra en unos pocos tonos: gris, oro, verde, violeta y blanco. De hecho, los arreboles de las últimas luces de la tarde pueblan el entero libro, que se basa en una armonía de matices dorados y rosas, combinados ocasionalmente con violetas y malvas: «la tarde está rosa» (VIII), "hay lumbres amarillas / que son oro y rosas cálidas» (VIII), «todo bajo el cielo rosa / y el oro de tus pestañas» (XIII), «el malva / y el rosa del cielo harán / bien a las frondas doradas» (XIII), «Está naciendo la luna / sobre el río y está rosa / entre los árboles de oro / de la tarde melancólica» (XV), "Luna de oro, luna rosa» (XLVII), "Viejo jardín de elegía / romántico y amarillo [...]. / Y el dulce sol rosa y oro / sueña sobre el musgo verde» (L), «Y la luz llueve, velada / por las frondas... sólo un algo / de violeta de otro mundo, / de oro rosa, de azul pálido» (LXIII), «Estoy envuelto en la tarde / como en un sueño violeta

68. La cita pertenece a un texto polémico redactado contra las innovaciones de la poesía de Rubén Darío y publicado entre los Ripios ultramarinos (Montón tercero), Madrid, Librería General de Victoriano Suárez, 1896. Este divertido artículo ha sido recogido en la reciente antología de la obra del escritor leonés: Antonio de Valbuena, Prosa crítica, Nieves Algaba (éd.), León, Diputación de León, 2001, p. 149-162 (la cita en p. 152).

69. Jardines lejanos, p. 136-137. 
[...]. / Todas las horas de idilio, / de jardín y de leyenda; / ¡el naciente rosa y oro / de todas las lunas nuevas!» $(\mathrm{LXX})^{70} \ldots$

Pese a que esta idea no parece haber calado en el ámbito de la crítica juanramoniana, podría sospecharse que en el libro Jardines lejanos late el ambicioso prurito de integrar las tres artes hermanas: la pintura, la poesía, la música. De manera difusa, más allá del mero ideal de abolengo wagneriano, podría vincularse tal aspiración a los denominados libros de arte que habían poblado el panorama modernista catalán, como las citadas Oracions, surgidas de la colaboración entre Rusiñol (poesía), Utrillo (imagen) y Morera (música). Los poemas se conciben, ante todo, como pequeños cuadros poblados de imágenes vagas y melancólicas, al modo de algunos lienzos de Rusińol o del Sorolla más íntimo y retraído. En segundo lugar, no puede olvidarse cómo cada una de las tres secciones del volumen aparece encabezada, respectivamente, por una partitura de Gluck (Gavota, Grasiosamente); de Schumann (Dolor sin fin, Lentamente) y de Mendelssohn (Romanza sin palabras, Andante con moto). Cada tipo de jardín (ya sean éstos galantes, místicos o dolientes) tiene una música remota que lo identifica, así como su propio ritmo, según los designios establecidos por el escritor en tales preámbulos melódicos. Por último, al uso de estos contrapuntos de naturaleza musical, añade Juan Ramón el confesado homenaje a sus modelos literarios, que irrumpen en el libro a través de varios mottos o lemas ${ }^{71}$. Por ejemplo, la entera sección de los Jardines galantes aparece presidida por la cita de cuatro versos verlainianos, procedentes de una de las composiciones más celebradas de las Fêtes galantes: el Clair de lune $e^{72}$. En la juvenil obra juanramoniana a través de las citas engastadas vemos la conexión directa que se establece con la idea simbolista de los paysages de l'âme. De hecho, el arranque del texto de Verlaine al que acabamos de aludir comienza: «Votre âme est un paysage choisi». Ecos similares podrían rastrearse en otros lemas engastados a lo largo del libro, como sucede con el poema tercero de los Jardines dolientes, presidido por dos endecasílabos de Georges Rodenbach (1855-1898), que cierran su conocida pieza Douceur du soir! ${ }^{73}$. También en

70. Sobre el valor simbólico de los colores y las asociaciones sinestésicas durante el fin de siglo, cabe remitir ahora al trabajo de José Luis Bernal Muñoz, «El color en la literatura del Modernismo", Anales de Literatura Española, 15, 2002, p. 171-191. Al abordar la obra de J. R. Jiménez, el estudioso afirma: «En el escritor de Moguer el paisaje es color y el color es poesía. Rojos son sus Jardines galantes, blancos sus Jardines misticos, dorados y malvas sus Jardines dolientes» (p. 176).

71. Sobre las lecturas del poeta, es de obligada consulta la monografía de Soledad González Ródenas, Juan Ramón Jiménez a través de su biblioteca. Lecturas y traducciones en lengua francesa e inglesa (1881-1936), Sevilla, Universidad de Sevilla, 2005.

72. Se trata de los versos 5-8 del poema: «Tout en chantant sur le mode mineur / l'amour vainqueur et la vie opportune, / ils n'ont pas l'air de croire à leur bonheur / et leur chanson se mêle au clair de lune...».

73. «Douceur du soir! Douceur de la chambre sans lampe! / Le crépuscule est doux comme une bonne mort / et l'ombre lentement qui s'insinue et rampe / et déroule en fumée au plafond. Tout s'endort. / Comme une bonne mort sourit le crépuscule / et dans le miroir terne, en un geste d'adieu, / il semble doucement que soi-même on recule, / qu'on s'en aille plus pâle et qu'on 
este poema el autor de Bruges la Morte establece una identidad similar: «Des tableaux appendus aux murs, dans la mémoire [...] / paysage de l'âme et paysages peints».

El recorrido por estos juanramonianos jardines de senderos que se bifurcan entre lo lírico y lo plástico, entre lo literario y lo musical, podría cerrarse ahora con un poema breve publicado en 1906 en el volumen Las hojas verdes. Significativamente, el libro estaba dedicado al pintor Emilio Sala, al que concede el honroso título de "maestro de rosas». De alguna manera, el texto sigue los modos ya vistos en otras composiciones, aunque en este Jardín de octubre se cargan ahora de valencias meta-poéticas:

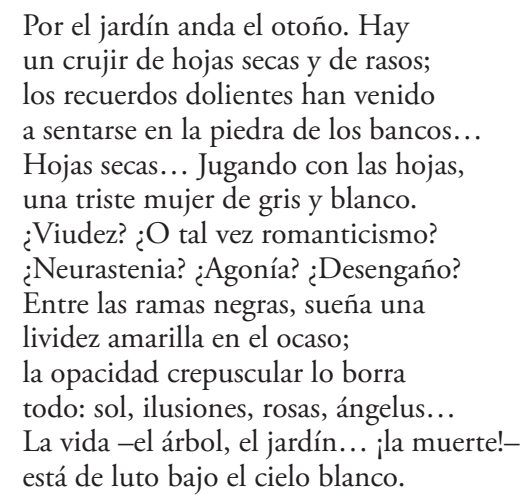

Como las vagarosas figuras femeninas de un Whistler, la dama de gris y blanco encarna no sólo el enfermizo atractivo de la mujer remota, sino también el espíritu de una época que se mueve aún en la deriva tardía del Romanticismo, asumiendo los rasgos propios de la decadencia («neurastenia, agonía»). De hecho, la ambientación de esta escena otoñal se ha relacionado con algunos elementos de la pintura prerrafaelita de Dante Gabriel Rossetti: «Jiménez se contenta con llevar a las amadas ideales a parques silenciosos (los parques viejos del modernismo) para ver cómo en sus ojos se refleja el color del cielo y la melancolía de los crepúsculos; para ceñir su cabeza con diademas de rosas; para llorar juntos, perdidos en la bruma, por la muerte de la tardes ${ }^{74}$.

y meure un peu. / Des tableaux appendus aux murs, dans la mémoire / où sont les souvenirs en leurs cadres déteints, / paysage de l'âme et paysages peints, / on croit sentir tomber comme une neige noire. / Douceur du soir! Douceur qui fait qu'on s'habitue / à la sourdine, aux sons de viole assoupis ; / l'amant entend songer l'amante qui s'est tue / et leurs yeux sont ensemble aux dessins du tapis. / Et langoureusement la clarté se retire ; / douceur! Ne plus se voir distincts ! N'être plus qu'un!/ Silence! deux senteurs en un même parfum : / penser la même chose et ne pas se le dire".

74. Ricardo Gullón, «Juan Ramón Jiménez y los Prerrafaelitas», Estetas y decadentes, Madrid, J. Tablate Miquis Ediciones, 1985, p. 77-80 (la cita en p. 78). 


\section{UN POLÍPTICO MACHADIANO: ADHESIÓN Y HASTÍO}

La lírica machadiana aparece vertebrada por un conjunto de motivos de gran densidad simbólica: la fuente, el camino, el atardecer... La bibliografía sobre tales elementos resulta en verdad nutrida, mas, en marcado contraste con tal floración de estudios, la crítica no parece haber mostrado especial interés en la trascendencia que el motivo del jardín llegó a asumir entre los primeros textos de Antonio Machado. A nuestro juicio, la ambivalente visión machadiana del jardín puede reconocerse en un curioso políptico integrado por cinco poemas, donde se evidencia la adhesión inicial a dicha temática -asumida con todos sus matices- y el paulatino desapego y hastío de la misma, que le lleva finalmente a ejecutar sobre ella una revisión irónica ${ }^{75}$. Sin duda, una parte fundamental en dichos tanteos se relaciona con la tradición de los poemas pictóricos de matriz simbolista, hasta el punto que un análisis demorado de los jardines líricos de Antonio Machado permitiría reconstruir las relaciones del poeta sevillano con otros autores del momento, así como el fértil diálogo que sus versos entablan con los de un poeta algo más joven (Juan Ramón Jiménez).

Para acotar las posibles visiones que pueblan los jardines machadianos, ante todo conviene revisar uno de los textos descartados de la segunda edición de Soledades. Como bien se recordará, el principal conjunto de poemas que integraba dicho libro fue compuesto entre 1899 y 1902. La edición príncipe del volumen salía de las prensas fechada en 1903 e incluía cuarenta y dos composiciones. Después de un intenso trabajo de selección y rescritura, el autor prescindió de trece de los poemas primigenios e introdujo numerosas variantes en la segunda redacción de las restantes composiciones ${ }^{76}$. Acompañados de otros sesenta y seis textos nuevos, en 1907 veía la luz el remozado volumen, titulado ahora Soledades, galerías y otros poemas. Entre los textos rechazados por el autor sevillano en la segunda edición de la obra, puede localizarse uno de especial relevancia para nuestro estudio. Desde el propio título, el poema evoca la característica identificación entre el motivo crepuscular y el sombrío espacio de la melancolía: La tarde en el jardín. Fragmento. Examinemos seguidamente sus versos:

\footnotetext{
Era una tarde de un jardín umbrío, donde blancas palomas arrullaban un sueño inerte, en el ramaje frío. Las fuentes melancólicas cantaban. El agua un tenue sollozar riente
}

75. Recientemente, ha indagado sobre la conexión del escritor con el Simbolismo el crítico y poeta Jorge Urrutia: «La significación de Soledades», «De nuevo sobre el simbolismo ideológico machadiano", en Las luces del crepúsculo, Madrid, Biblioteca Nueva, 2004, p. 191-206 y 207225. Sobre la écfrasis machadiana, remito a Jesús María Monge, «La realidad poético-pictórica de Fantasía iconográfica de Antonio Machado", Abel Martín. Revista de Estudios sobre Antonio Machado, Noviembre 2003, p. 1-14. http://www. abelmartin.com/crit/monge_d.html

76. José María Rodríguez García, "Cien años de Soledades, galerías y otros poemas: presente y pasado en Antonio Machado», Revista de literatura, LXXI, 141, 2009, p. 137-156. 
en las alegres gárgolas ponía

y por estrecho surco, a un son doliente, entre verdes evónimos corría.

Era un rincón de olvido y sombra y rosas

frescas y blancas entre lirios. Era donde pulsa en las liras olorosas recónditas rapsodias Primavera, y más lejos se ve que el sol esplende oculto tras la tapia ennegrecida, que el aire sueña, donde el campo tiende su muda, alegre soledad florida.

¡Noble jardín, pensé, verde salterio que eternizas el alma de la tarde, y llevas en tu sombra de misterio estrecho ritmo al corazón cobarde y húmedo aroma al alma! En tus veredas silenciosas, mil sueńos resucitan de un ayer, y en tus anchas alamedas claras, los serios mármoles meditan inmóviles secretos verticales más graves que el silencio de tus plazas, donde sangran amores los rosales y el agua duerme en las marmóreas tazas. Secretos viejos del fantasma hermano que a la risa del campo, el alto muro dictó y la amarga simetría al llano donde hoy se yergue el cipresal obscuro, el sauce llora y el laurel cimbrea, el claror de los álamos desmaya en el ambiente atónito y verdea en el estanque el esplendor del haya. Cantar tu paz en sombra, parque, el sueño de tus fuentes de mármol, el murmullo de tus cantoras gárgolas risueño, de tus blancas palomas el arrullo, fuera el salmo cantar de los dolores que mi orgulloso corazón encierra: otros dolores buscan otras flores, otro amor, otro parque en otra tierra ${ }^{77}$.

El incipit del poema (que sirve también de lema a estas reflexiones) marca el hic et nunc: «la tarde» en un «jardín» poblado por las sombras. Un conjunto de signos configuran la atmósfera propia de la lírica simbolista: «sueńo inerte», «fuentes melancólicas», «tenue sollozar», «son doliente», «olvido y sombra». El espacio cerrado de este «noble jardín» sirve así para despertar la meditación del locutor poético, que lee en los vegetales signos como si de un antiguo libro de música se tratara, un "verde salterio» en el que se copia como un "salmo» la eterna

77. Ed. cit., pp. 399-400. La concatenación que cierra melancólicamente el poema parece acoger algún eco difuso de un celebérrimo pasaje de la primera égloga de Garcilaso (vv. 400406): «Y en la tercera rueda, / contigo mano a mano, / busquemos otro llano, / busquemos otros montes y otros ríos, / otros valles floridos y sombríos / donde descanse y siempre pueda verte / ante los ojos míos» (Obra poética y textos en prosa, Bienvenido Morros (ed.), Barcelona, Crítica, 2007, p. 218). 
repetición y el incumplimiento ${ }^{78}$. Desde el punto de vista estructural, conviene apuntar cómo el poema aparece férreamente marcado por una composición en anillo: los ocho versos iniciales se reflejan -con leves matices- en los últimos ocho endecasílabos. Una brillante investigación sobre este tipo de técnica había evidenciado cómo «la circularidad tiene [varias] lecturas simultáneas», entre las que destaca «la constatación de una simultaneidad del sentido para fijar un momento estático» en un conjunto de poemas hechos de "pinceladas paisajísticas e impresionistas aisladas» que pretenden «embarcarnos en un ciclo de repetición infinita ${ }^{79}$. En definitiva, La tarde en el jardin representa una de los más logrados poemas machadianos desde la óptica simbolista y decadente, ya que entre sus versos confluyen la musicalidad exquisita y la decidida vocación plástica ${ }^{80}$. Desde el punto de vista de las afinidades estéticas, ya se había subrayado cómo algunos "versos y actitudes" presentes en las Rimas y las Arias tristes de Juan Ramón Jiménez pudieron dejar huella en la poesía de los hermanos Machado: «los diálogos con el alma y con el paisaje, las flores secas del corazón, la tristeza de recuerdos en el aire tranquilo del jardín ${ }^{81}$.

La siguiente presencia del motivo en la lírica machadiana nos guía ahora hasta un texto dedicado, en prenda de amistad, a Juan Ramón Jiménez ${ }^{82}$. La composición entabla un sugestivo diálogo con los Jardines lejanos del moguereño, en especial con algunos textos de su sección primera, los Jardines galantes. Antes de acometer el estudio del mismo, conviene apuntar cómo desde el punto de vista biográfico, el texto se inserta en un entorno de camaradería literaria, propio de la boga modernista de los años 1902-1904. De hecho, hay que recordar que el propio Juan Ramón Jiménez cuando diera a las prensas sus Jardines lejanos,

78. El pequeño motivo del salmo vegetal aparece también en otro de los poemas descartados en la edición de 1907, en asociación significativa con la época autumnal, de resonancias verlainianas. El breve poema se titula Otoño: «El cárdeno otoño / no tiene leyendas / para mí. Los salmos / de las frondas muertas / jamás he escuchado, / que el viento se lleva. / Yo no sé los salmos / de las hojas secas, / sino el sueńo verde / de la amarga tierra». Ed. cit., p. 397.

79. Ángel Luis Luján Atienza, "La estructura circular en la poesía post-romántica y el Modernismo. Avatares en la creación del sentido poético», Iberoromania, 60, 2004, p. 59-81. La cita se sitúa en p. 75.

80. Pese a que el poema XXVIII ("Crear fiestas de amores») no esté marcado por ninguna intención visual, debe apuntarse cómo al cierre del mismo el autor se recrea en varios elementos propios del motivo (el ave que con su trino establece una suerte de contrapunto sonoro, la soledad, la sombra, el sueño, el abandono sensorial en el jardín): «Un pájaro escondido entre las ramas / del parque solitario / silba burlón... Nosotros exprimimos / la penumbra de un sueño en nuestro vaso... / Y algo, que es tierra en nuestra carne, siente / la humedad del jardín como un halago» (ed. cit., p. 106). Por otro lado, cabe recordar que la composición XXX establece una identidad entre las imágenes de la memoria, el sueño y los cuadros de paisaje intimista en sus primeros versos: «Algunos lienzos del recuerdo tienen / luz de jardín y soledad de campo; / la placidez del sueño / en el paisaje familiar soñado» (p. 107).

81. Biruté Ciplijauskaité, "Albert Samain, Juan Ramón Jiménez y Antonio Machado», Congreso Internacional Conmemorativo del centenario de Juan Ramón Jiménez, Huelva, Diputación de Huelva, 1983, vol. I, p. 233-241 (la cita en p. 233).

82. Ricardo Gullón, Relaciones entre Antonio Machado y Juan Ramón Jiménez, Pisa, Università degli Studi di Pisa, 1964. 
había dedicado la tercera sección del libro (los Jardines dolientes) a Antonio Machado. Unas páginas de Rafael Cansinos Assens permiten vislumbrar el tono de las reuniones poéticas frecuentadas por Villaespesa, los Machado, Antonio de Zayas, Juan Ramón Jiménez y Ortiz de Pinedo al comenzar el siglo. Unidos por similares intereses literarios, varios amigos deciden rendir visita al escritor onubense, que acaba de instalarse en la madrileña clínica del Rosario, dirigida por el doctor Simarro. Allí Cansinos dibuja este fresco vital:

Una enfermera, discreta, pulcra y sigilosa, nos guiaba hasta el departamento que allí ocupaba el poeta de las Rimas. Una habitación medianamente grande, con ventanas al jardín, confortable como un cuarto de hotel caro, en la que ya había luz encendida, una mesa con libros y papeles en el centro, una chimenea francesa en uno de los testeros, con retratos, flores y libros sobre su tapa de mármol y algunos grabados en las paredes. Todo pulcro, elegante, correcto. $\mathrm{Y}$ en aquel marco de selección, el poeta, pulcro, correcto también, joven, fino, pálido, serio y triste, con unos grandes ojos negros y melancólicos, un leve bigotillo negro y una barbita en punta, como la de D'Annunzio, tendiéndonos la mano suave y pálida, lacia, en un gesto de fría cordialidad [...]. Su atención se dirigía más bien a los Machado, sobre todo a Antonio, grave y discreto: «Sí, no está esto mal... Tengo un balcón con mirador sobre el jardín, donde los días de sol y las noches de luna, me embriago de ensueño y de oro y azul... Aquí me tratan bien... Francina cuida de que nunca falten aquí flores... Ya me ha traído las primeras violetas...». Y señalaba a un jarrón de cristal sobre la chimenea [....]. Leeré algo de mi próximo libro Arias tristes - y lee- Mi jardín tiene una fuente / y la fuente una quimera / y la quimera un amante / que se muere de tristeza... Otra vez Villaespesa exclama: ¡Admirable! ¡Sencillamente admirable! Antonio Machado dice: Tiene usted la flauta de Verlaine ${ }^{83}$.

La estampa biográfica que bosqueja Cansinos Asséns permite asomarse a los encuentros de los renovadores modernistas, así como las sutiles afinidades que existían entre ellos. El cronista pone algún énfasis en el interés que sobre Juan Ramón ejerce Antonio Machado: «su atención se dirigía más bien a los Machado, sobre todo a Antonio». Tras declamar sus versos (de nuevo un poema de jardín) el refinado escritor de Moguer recibe el cumplido del autor de Soledades, que compara la musicalidad de su poesía con el ritmo melancólico del autor de las Fêtes galantes: «Tiene usted la flauta de Verlaine» ${ }^{84}$. A la luz de

83. "Juan Ramón Jiménez», La novela de un literato, Madrid, Alianza, 2005, vol. I, p. 159168 (los textos proceden de p. 162-166).

84. Antonio Machado agradecería la dedicatoria de la tercera parte de los Jardines lejanos con una emotiva carta al joven escritor onubense: «Queridísimo poeta: Gracias mil por su dedicatoria y por haberme incluido entre sus poetas favoritos. Mucha gloria es para mí: demasiada [...]. Su libro es sencillamente admirable y lo mejor, a mi juicio, Jardines dolientes. Paréceme, en suma, una obra madura y perfecta. Una tan fina sensibilidad como la de usted no existe, creo yo, entre poetas castellanos; tal dulzura de ritmo y delicadeza para las armonías apagadas, tampoco. Suavidad de sonidos, de tonos, de imágenes, de sentimientos. Sedas marchitas o fronda mustia a través de un cristal algo turbio a través de la lluvia. Usted ha oído los violines que oyó Verlaine y ha traído a nuestras almas violentas, ásperas y destartaladas otra gama de sensaciones dulces y melancólicas. Usted continúa a Bécquer, el primer renovador del ritmo interno de la poesía española, y le supera en suavidad. Mucho quisiera decir de usted y acaso acierte a decir algo. Por de pronto, ahí le dedico esos versos que su libro me inspira [...]. Sepa cuánto le quiere y admira, Antonio». Tomo la cita del conjunto de textos cuidado por Ricardo Gullón: Relaciones entre Antonio Machado y Juan Ramón Jiménez, Pisa, Università di Pisa, 1964, p. 42. 
estos datos, podemos volver ahora al tributo lírico de Machado a Juan Ramón, titulado significativamente Los jardines del poeta:

\author{
El poeta es jardinero. En sus jardines \\ corre sutil la brisa \\ con livianos acordes de violines, \\ llanto de ruiseńores, \\ ecos de voz lejana y clara risa \\ de jóvenes amantes habladores. \\ Y otros jardines tiene. Allí la fuente \\ le dice: - «Te conozco y te esperaba». \\ Y él, al verse en la onda transparente: \\ - «iApenas soy aquel que ayer sońaba!». \\ $\mathrm{Y}$ otros jardines tiene. Los jazmines \\ añoran ya verbenas del estío, \\ y son liras de aroma estos jardines, \\ dulces liras que tañe el viento frío. \\ $Y$ van pasando solitarias horas, \\ y ya las fuentes, a la luna llena, \\ suspiran en los mármoles, cantoras, \\ y en todo el aire sólo el agua suena ${ }^{85}$.
}

No parece baladí que el arranque de los versos plantee la identidad entre dos artes afines (la poesía y la jardinería), tal como preconizara Santiago Rusiñol desde las palabras liminares del volumen Jardines d'Espanya: «Els jardins són el paisatge posat en vers, i els vers escrits en plantes van escassejant pertot arreu; és que els jardins són versos vius, versos amb saba i amb arom, i com el jardiner poeta ${ }^{86}$. La identidad que aquí se establece entre la lírica y el ars topiaria viene acompañada de otros elementos que podrían identificarse como guiños cómplices dirigidos al joven creador homenajeado. De hecho, desde la misma presentación inicial ( $\mathrm{El}$ poeta es jardinero. En sus jardines / corre sutil la brisa / con livianos acordes de violines») pueden reconocerse algunos de estos acordes. En efecto, la asociación musical «jardines-violines» no sólo tiene resonancias verlainianas, sino que parece apuntar al arranque mismo de la colección juanramoniana de los Jardines lejanos: «Esta noche los jardines / tienen plata y seda, en una / luz de fiesta; los violines / se han prendado de la luna ${ }^{87}$. Como se ha visto, la música tiene una significación capital en el libro poético del moguereño, que reitera la misma asociación de palabrasrima en el poema XXVII de la sección consagrada a los Jardines galantes: «Esta noche en los jardines / llenos de faroles rojos / lloran los tristes violines / valses que nublan los ojos» ${ }^{88}$. Más allá de tales coincidencias, los versos machadianos podrían albergar otros sutiles homenajes, como el endecasílabo "iApenas soy aquel que ayer sońaba!». No parece descabellado intuir en el verso un eco de la tenue reminiscencia virgiliana, que habría de emplear también Darío para

85. Ed. cit., p. 408

86. S. Rusiñol, Obres completes, Barcelona, Editorial Selecta, 1976, t. II, p. 687.

87. Jardines lejanos, Madrid, Visor-Diputación de Huelva, 2007, p. 27.

88. Ibidem, p. 86. 
inaugurar los Cantos de vida y esperanza: «Ego sum ille qui quondam» / "Yo soy aquel que ayer no más decía ${ }^{89}$.

El epistolario inédito de Juan Ramón recoge alguna misiva en la que se puede ver el afecto que ambos escritores se siguen profesando años más tarde (la carta está datada en Moguer, Febrero de 1912) ${ }^{90}$ :

Queridísimo Antonio: Yo estoy bien aquí. No es que sienta nostalgia de la vida literaria de Madrid, que sabes bien que nunca la he hecho; pero aquí me faltan ciertos elementos de arte de los que no puedo prescindir; la música -conciertos-, ciertos aspectos de suntuosidad y de jardín [...]. Me dices que no me olvidas. Bien sabes que a mí me sucede lo propio contigo. Podrán olvidarse los que se pasan la vida en la balanza. Nosotros, los honrados, los nobles, los verdaderos no podemos olvidarnos nunca. Te abraza, JR

Curiosamente, los elementos de la vida "cultural» y «artística» madrileńa que añora Jiménez son los conciertos de música clásica y algunos «elementos de arte» que concretamente relaciona con "ciertos aspectos de suntuosidad y de jardín». Un oído atento a las melodías juanramonianas no puede sino evocar los famosos versos iniciales del poema segundo de los Jardines galantes: «Hay un oro dulce y triste / en el malva de la tarde / que da realeza a la bella / suntuosidad de los parques».

Si bien, las dos primeras contribuciones machadianas al motivo del jardín están ancladas en la temática fin-de-siècle (melancolía, crepúsculo, decadencia, tono doliente, ensońación...), la lírica del sevillano pronto habría de afrontar otros derroteros, que le encaminan ya a los núcleos temáticos de su madurez. Como testimonio de dicho cambio, en primer lugar se puede examinar aquí el texto XIX de Soledades:
¡Verdes jardinillos, claras plazoletas, fuente verdinosa donde el agua sueña, donde el agua muda resbala en la piedra!... Las hojas de un verde mustio, casi negras de la acacia, el viento de septiembre besa, y se lleva algunas amarillas, secas, jugando, entre el polvo blanco de la tierra.

\author{
Linda doncellita \\ que el cántaro llenas \\ de agua transparente, \\ tú, al verme, no llevas \\ a los negros bucles \\ de tu cabellera, \\ distraídamente, \\ la mano morena, \\ ni, luego, en el limpio \\ cristal te contemplas... \\ Tú miras al aire \\ de la tarde bella, \\ mientras de agua clara \\ el cántaro llenas ${ }^{91}$.
}

Al igual que se veía en las composiciones precedentes, en el texto puede percibirse aún cierta «vocation picturale», fácilmente reconocible en los once

89. Rubén Darío, Azul. Cantos de vida y esperanza, José María Martínez (ed.), Madrid, Cátedra, 2000, p. 339.

90. Epistolario (1898-1916), Alfonso Alegre Heitzmann (éd.), Madrid, Residencia de Estudiantes, 2006, t. I, p. 316-317.

91. Antonio Machado, Poesías completas (ed. Manuel Alvar), Madrid, Espasa Calpe, 1990, pp. 101-102. 
calificativos que inciden en valores cromáticos o luminosos: "verdes», «claras», «verdinosa», «verde», «negras», «amarillas», «blanco», «transparente», «negros», «morena», «clara». Ciertos detalles remiten asimismo a una especie de décor autumnal, no exento de vagas resonancias verlainianas: las hojas caídas que el viento de septiembre mueve a su capricho, el sueño de las aguas mudas en la fuente. Ahora bien, la atmósfera crepuscular y decadente que reconocíamos en los textos anteriores aparece ahora matizada por un elemento extraño a esa cosmovisión. De hecho, el romancillo hexasilábico se plantea como reflejo de una suerte de escena tradicional, donde un yo lírico masculino da cuenta de su visión de una hermosa muchacha que va a recoger agua a la fuente. La «linda doncellita» ignora a este varón anónimo, pues aparece sumida en sus pensamientos, una tarde otoñal de septiembre.

El jardín abandonado que cantaran Rusiñol, Jiménez o Marquina como espacio de la decadencia paulatinamente se transforma en la poesía de Antonio Machado en un espacio con figuras, donde la vida y el bullicio han dejado su huella. De hecho, la siguiente incursión del poeta sevillano en la temática del hortus conclusus podría considerarse al modo de una sensible variación que va camino de la interpretación irónica del motivo. El jardín aparece ahora como un «parque invernal» donde se refugian nińos y ancianos (Sol de invierno, XCVI):

\author{
Es mediodía. Un parque. \\ Invierno. Blancas sendas; \\ simétricos montículos \\ y ramas esqueléticas. \\ Bajo el invernadero, \\ naranjos en maceta, \\ y en su tonel, pintado \\ de verde, la palmera. \\ Un viejecillo dice, \\ para su capa vieja: \\ - «iEl sol, esta hermosura \\ de sol!»... Los niños juegan. \\ El agua de la fuente \\ resbala, corre y sueña \\ lamiendo, casi muda, \\ la verdinosa piedra ${ }^{92}$.
}

Como se puede apreciar, la escena se construye con total parquedad de elementos: un anciano protegido por su capa disfruta del sol del mediodía, un grupo de niños absortos en sus juegos, apenas algún árbol (la palma y el naranjo) mientras la fuente marca con su caudal el paso del tiempo. La luz fría del invierno hispalense y el aspecto descarnado y triste de los árboles sin hojas aparece asimismo en la pintura de Sorolla. Una imagen como la del Jardín del Alcázar de Sevilla en invierno (fig. 12) podría servir de correlato visual a la escena machadiana. 


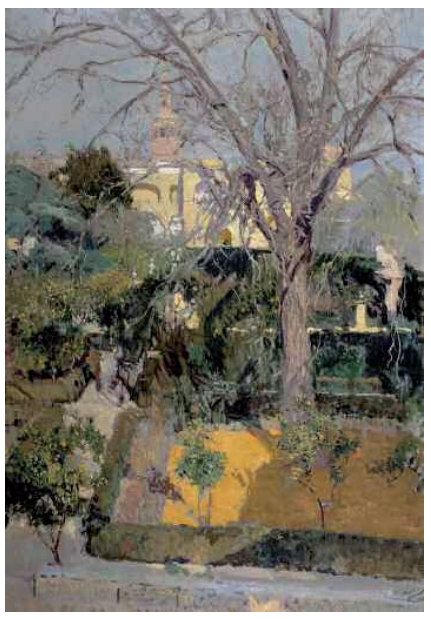

Fig. 12. Jardín del Alcázar de Sevilla en invierno (1908). Colección particular

Las indagaciones en torno a la visión machadiana del jardín finisecular pueden cerrarse ahora con el estudio de una composición breve (la LI, titulada escuetamente Jardinn), en la que el autor deja traslucir ya algún hastío, cierto distanciamiento irónico:

Lejos de tu jardín quema la tarde
inciensos de oro en purpurinas llamas,
tras el bosque de cobre y de ceniza.
En tu jardín hay dalias.
¡Malhaya tu jardín!... Hoy me parece
la obra de un peluquero,
con esa pobre palmerilla enana,
y ese cuadro de mirtos recortados...
y el naranjito en su tonel... El agua
de la fuente de piedra
no cesa de reír sobre la concha blanca ${ }^{93}$.

Todos los elementos del decorado poético que pergeña el escritor sevillano se han entrevisto en los poemas precedentes: el atardecer, las flores, la palma, los mirtos, el naranjo, la fuente marmórea... El arranque de este Jardín final se

93. Poesías completas, p. 124. Podría verse, a modo de contraste, el brevísimo poema XXXII, de marcados valores visuales, donde el crepúsculo sobre un parque aparece matizado por connotaciones mortuorias: «Las ascuas de un crepúsculo morado / detrás del negro cipresal humean... / En la glorieta en sombra está la fuente / con su alado y desnudo Amor de piedra, / que sueña mudo. En la marmórea taza / reposa el agua muerta». Ed. cit., p. 108. Según el autorizado juicio de Andrew P. Debicki, «el verso de Machado transforma las escenas y los elementos de la naturaleza en correlatos de actitudes subjetivas, evitando siempre el decorativismo que caracterizaba a los modernistas. En el poema XXXII, un paisaje incorpora un estado de ánimo negativo [...]. Todos los aspectos de la descripción -la imagen del crepúsculo como ascuas, los colores oscuros, la presencia de cipreses (que a menudo rodean los cementerios españoles), la reducción de la vida humana a una estatua muda, la palabra muerta- suscitan un sentido del tiempo que pasa y sugieren la finitud y la muerte». Historia de la poesía española del siglo XX. Desde la modernidad hasta el presente, Madrid, Gredos, 1997, p. 24 
antoja plástico y solemne, como si de un «barroco incendio de teatro» se tratara. La tarde se muestra calcinada "en purpurinas llamas», envuelta en el sahumerio de «inciensos de oro». Aquí el bosque se revela "de cobre y de ceniza», dejando apenas atisbar unas pocas «dalias». Los cuatro versos iniciales establecen, pues, una especie de preludio inflamado y soberbio, cuyo tono enfático abruptamente cae con el quinto endecasílabo. La imprecación siguiente («iMalhaya tu jardín!») no sólo sirve para execrar un espacio consagrado por la tradición pictórica y poética del fin de siglo, sino que también deja paso -como generosamente me apunta Mercedes Blanco- a una matizada "crítica al intimismo doméstico de los jardines como tema poético». Tras la pompa y el oropel de dicho crepúsculo, el escritor ahora se dispone a revelar unas cuantas verdades. Los diminutivos recalcan la dimensión ridícula que pretende atribuirse a tal escenografía: la «pobre palmerilla enana», el enclenque «naranjito en su tonel». De manera harto significativa, ya el Ars topiaria no se hermana-como en los versos dedicados a Juan Ramón Jiménez- con la sublime poesía, sino que la técnica de recortar setos y formar arquitecturas vegetales a golpe de tijera se degrada a la humilde «obra de un peluquero». A modo de broche anticlimático, el entero cuadro poético se convierte finalmente en objeto de risa: vertiéndose eterna «sobre la concha blanca» se ríe "el agua de la fuente». Del fragmento final del poema y su carácter excepcional en la obra del sevillano se ha llegado a afirmar que en estos versos «the poetic voice strikes an unusual note of personal animosity, apparently provoked by the sight of pretentious Andalousian kitsch» ${ }^{94}$.

\section{Jardines espectrales en Manuel Machado:} MUSICALIDAD Y DECADENCIA

En la memoria de los lectores españoles, más que a los versos de Antonio Machado, la visión en torno a los jardines del Fin de Siglo suele asociarse a la obra oscura, musical y melancólica de su hermano Manuel. Injustamente postergada por razones ideológicas, la «hora dulce de la rehabilitación» de la lírica de este escritor sevillano ha llegado, en parte, «de la mano de su poesía de tema pictórico» donde brilla con luz propia su acentuada «atracción por la decadencia ${ }^{95}$. De justificada fama goza el díptico de poemas titulados El jardín negro y El jardin gris, considerados entre las piezas clave de la obra de este autor:

\footnotetext{
Es noche. La inmensa palabra es silencio... Hay entre los árboles un grave misterio... El sonido duerme,
}

\author{
¡Jardín sin jardinero! \\ ¡Viejo jardín, \\ viejo jardín sin alma, \\ jardín muerto! Tus árboles \\ no agita el viento. En el estanque, el agua
}

94. Elizabeth Scarlett, «Antonio Machado's Fountains: Archeology of an Image», Modern Language Notes, 113, 2, 1998, p. 305-323 (la cita se encuentra en p. 315).

95. Enric Bou, «Decadencia e Imperio: la poesía pictórica de Manuel Machado», en AA. VV., Divergencias y unidad. Perspectivas sobre la generación del 98 y Antonio Machado, Madrid, Orígenes, 1990, p. 125-140 (la cita en p. 128). 
el color se ha muerto.

La fuente está loca

y mudo está el eco.

¿Te acuerdas?... En vano quisimos saberlo...

¡Qué raro! ¡Qué oscuro!

¡Aún crispa mis nervios, pasando ahora mismo tan sólo el recuerdo, como si rozado me hubiera un momento el ala peluda de horrible murciélago!... Ven, ¡mi amada! Inclina tu frente en mi pecho; cerremos los ojos; no oigamos, callemos... ¡Como dos chiquillos que tiemblan de miedo!

La luna aparece, las nubes rompiendo... La luna y la estatua se dan un gran beso ${ }^{97}$. yace podrida. ¡Ni una onda! El pájaro

no se posa en tus ramas.

La verdinegra sombra

de tus hiedras contrasta con la triste blancura de tus veredas áridas... ¡Jardín, jardín! ¿Qué tienes? ¡Tu soledad es tanta, que no deja poesía a tu tristeza! ¡Llegando a ti, se muere la mirada! Cementerio sin tumbas...

Ni una voz, ni recuerdos, ni esperanza. ¡Jardín sin jardinero! ¡Viejo jardín, viejo jardín sin alma! ${ }^{96}$

Conocida la pasión que el autor sevillano sintiera por la obra verlainiana, ambos textos se han vinculado a la lírica del pauvre Lélian, especialmente a uno de los más conocidos Poèmes saturniens, el texto III de la sección Melancholia (titulado Après trois ans), cuyo célebre comienzo reza: «Ayant poussé la porte étroite qui chancelle, / je me suis promené dans le petit jardin / qu'éclairait doucement le soleil du matin, / pailletant chaque fleur d'une humide étincelle. / Rien n'a changé. J'ai tout revu: l'humble tonnelle / de vigne folle avec les chaises de rotin...." ${ }^{98}$. En Manuel Machado, el espacio del jardín abandonado sirve de correlato objetivo a la abulia, al oscuro desánimo del yo lírico. El Jardín gris «recoge las descripciones típicas de un espacio habituado por la muerte» y avanza desde el propio título «la carencia cromática, vital y sensitiva de sus elementos», de forma que el «tono amorfo significa la imprecisión anímica

96. Manuel Machado, Alma. Ars moriendi, Pablo del Barco (ed.), Madrid, Cátedra, 1995, p. 92.

97. Ibidem, p. 126.

98. Fêtes galantes. Poèmes saturniens, Chantal Bordier (ed.), Paris, Gallimard, 2005, p. 49. El eco de este poema resuena de forma mucho más evidente en la obra de Antonio (en el arranque del poema VI de Soledades): «Fue una clara tarde, triste y sońolienta / tarde de verano. La hiedra asomaba / al muro del parque, negra y polvorienta... / La fuente sonaba. / Rechinó en la vieja cancela mi llave; / con agrio ruido abrióse la puerta / de hierro mohoso y, al cerrarse, grave / golpeó el silencio de la tarde muerta. / En el solitario parque, la sonora / copla borbollante del agua cantora / me guió a la fuente. La fuente vertía / sobre el blanco mármol su monotonía» (ed. cit., p. 91). Acotaba las semejanzas entre ambas composiciones Rafael Ferreres en Verlaine y los modernistas españoles, Madrid, Gredos, 1975, p. 139. 
del poeta»99. Por su parte, el Jardín negro recurre a un tipo de efectismo que la crítica ha asociado al influjo de Francisco Villaespesa, que elaboraba un tema similar en el poema Los murciélagos $^{100}$. Simbolismo y Decadencia van de la mano en ambos textos, cuya lectura «nos deja una sensación de desesperanza, de desolación, de ruina, de tristeza plana, abrumadora, sin remedio» ${ }^{101}$.

Pero más allá del inequívoco regusto «saturniano» o melancólico de las dos composiciones del díptico, conviene subrayar ahora -tal como revelara Miguel D’Ors- que uno de los modelos evocados por el Jardín gris de Manuel Machado permite vincular sin paliativos tales versos a la estética decadente. Se trata de un complejo texto de Gabriele D'Annunzio, el poema Hortus conclusus recogido en su Poema paradisiaco (1893) ${ }^{102}$. Al cotejar los versos de ambas piezas, la aproximación machadiana al escenario finisecular se antoja muy semejante a la de algunos fragmentos del gran lírico italiano:

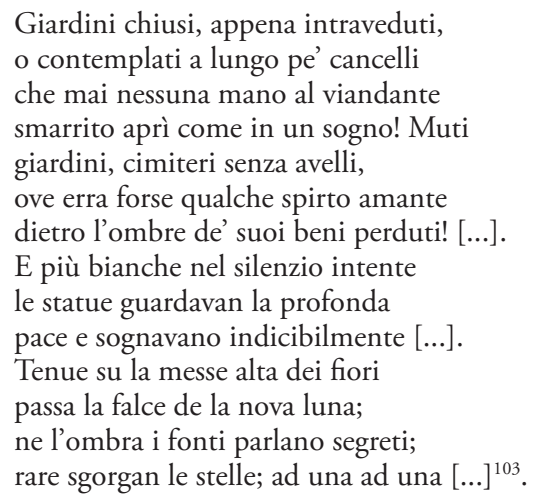

En cierto modo podría hablarse de una línea sutil que recorre la lírica europea del momento, estableciendo una identidad morbosa entre los jardines en decadencia y el espacio funéreo del camposanto: «Muti / giardini, cimiteri senza avelli» (Dannunzio), «la bellesa enterrada en son mateix cementiri» (Rusińol), "Jardín muerto [...] / cementerio sin tumbas» (M. Machado). Sin duda, el magisterio de uno de los grandes santones del Decadentismo internacional que evidencia el Jardín gris invita a reflexionar acerca de los tintes más lúgubres y efectistas que el motivo lleva aparejado por otros predios. Si nos fijamos en la lírica francesa, puede aducirse un curioso poema de Albert Samain (18581900), publicado en el influyente volumen $A u$ jardin de l'Infante. El texto presenta con breves pinceladas la ambientación de un jardín nocturno, poblado

99. Carolina Corbacho Cortés, «El léxico cromático en la poesía de Manuel Machado», Actas del I Congreso Internacional de Historia de la Lengua española, 1988, vol. I, p. 767-778 (p. 773).

100. Gordon Brotherston, Manuel Machado, Madrid, Taurus, 1976, p. 107.

101. Luis Antonio de Villena, Máscaras y formas del Fin de Siglo, Madrid, Valdemar, 2002, p. 143.

102. Miguel D’Ors, Estudios sobre Manuel Machado, Sevilla, Renacimiento, 2000, p. 38-40.

103. Gabriele D'Annunzio, Versi d'amore e di gloria (ed. Luciano Anceschi), Milano, Mondadori, 2006, vol. I, p. 610-611. 
por el denso aroma de los jazmines, para rápidamente dar paso a la evocación de las matanzas del anfiteatro romano, en tanto correlato de los sufrimientos de amor:

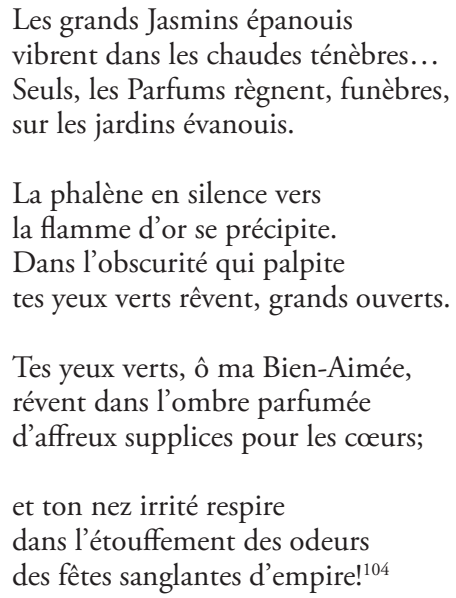

Junto al magisterio imponente de Verlaine, durante sus años parisinos Manuel Machado había admirado profundamente la obra de los maestros simbolistas y los escritos de los grandes autores vinculados al Decadentismo. Pese a que el matiz de sugerencia y evocación que presenta la lírica de Samain no fue bien aprehendido por el inquieto sevillano, creo que un experimento como el del Jardín negro puede vincularse a este tipo de lecturas, mezcladas aquí con cierto efectismo tenebroso que evoca lejanamente las turbadoras imágenes de Goya ${ }^{105}$. De hecho, conviene recordar cómo en la escritura de Antonio Machado y Juan Ramón Jiménez se ha identificado el poso de la «nostalgia indefinible, la sensación de pérdida inconsolable» que define una obra como $A u$ jardin de l'Infante, admirada en la época "por su delicadeza», por su inclinación a lo «inefable» ${ }^{106}$.

Los paralelos de la poesía manuelmachadiana con la lírica decadente podrían multiplicarse, ya que la estrategia de elaborar de manera plástica la materia verbal fue acometida con denuedo por los máximos exponentes de

104. Au jardin de l'Infante, Paris, Mercure de France, 1911, p. 23-24.

105. Desde una cronología posterior, la presencia simbólica del murciélago también irrumpe entre los versos de un pintor tan conocido como Filippo de Pisis. En una composición breve titulada Sera puede identificarse a dicho animal tenebroso: «Nel grigio fine / un pipistrello nero / (gotica romantica l'ala perversa) / leggero come il fumo / de la mia lunga pipa / di gesso e di canna. / Fuligini e velluti neri attorno / a un pertugio centenario / su un muro rosso, / abbaini e lucernai / sul vecchio tetto di fronte, / camini sensibili / e voli, / foglie verdi embricate sul muretto. / Il mio cuore amaro, pacificato / attende un ignoto bene. / Due viole turche sul davanzale. / Sante campane d'ore e di festa / incrinano l'aria appena». Poesie, Giovanni Raboni (éd.), Milano, Garzanti, 2003, p. 148.

106. Biruté Ciplijauskaité, "Albert Samain, Juan Ramón Jiménez y Antonio Machado», Congreso Internacional Conmemorativo del centenario de Juan Ramón Jiménez, Huelva, Diputación de Huelva, 1983, vol. I, p. 233-241 (la cita en p. 239). 
esta corriente internacional. Por aducir otro paralelo significativo, Oscar Wilde compuso un interesante díptico de poemas breves titulado Impressions (1882), rindiendo homenaje sus maestros franceses ${ }^{107}$. La primera composición del mismo se titula Le jardin, la segunda pieza se rubrica como La mer. Como avanzan los propios títulos, estas dos composiciones guardan una relación muy estrecha con las artes visuales, en tanto que evocan líricamente (mediante el encuadre) géneros tan conocidos como la pintura de jardín y la marina ${ }^{108}$. Por cuanto ahora nos atańe, el poema Le jardin aborda el argumento como si de una yuxtaposición de primeros planos se tratara:

\author{
The lily's withered chalice falls \\ around its rod of dusty gold, \\ and from the beech-trees on the wold \\ the last wood-pigeon coos and calls. \\ The gaudy leonine sunflower \\ hangs black and barren on its stalk, \\ and down the windy garden walk \\ the dead leaves scatter, -hour by hour. \\ Pale privet-petals white as milk \\ are blown into a snowy mass: \\ the roses lie upon the grass \\ like little shreds of crimson silk ${ }^{109}$.
}

La composición se articula como una sucesión de manchas de color, de masas cromáticas que van del oro al negro, del verde al blanco, hasta culminar en un rojo encendido. A través de una escogida adjetivación, el poeta da cuenta del paso del tiempo, avisando de la inminente corrupción de la materia: «withered chalice», «dead leaves», «pale petals». El juego de pequeños detalles pictóricos (lirio, haya, paloma, girasol, pétalos de alheña) y el establecimiento de una paleta de colores simbólicos se antoja bastante próximo al de las técnicas que más tarde habrían de desarrollar autores españoles tan diferentes como el propio Manuel Machado o Juan Ramón Jiménez.

107. Peter Wagner, «Oscar Wilde’s Impression du matin. An Intermedial Reading», en Icons, texts, iconotexts: essays on ekphrasis and intermediality, Peter Wagner (ed.), Berlin-New York, De Gruyter, 1996, p. 281-306 (en especial, p. 285-288).

108. No hay que olvidar que, desde los postulados de una línea ya avanzada por Baudelaire, el propio Wilde preconizó en un ensayo de 1890 ( $T$ The Critic as Artist») que el mejor crítico de una obra de arte visual era el poeta. Ha dedicado una importante contribución a esta materia Micéala Symington, «Poétique de la critique picturale symboliste», Modern Language Notes, 114, 5, 1999, p. 1110-1118.

109. The complete Works of Oscar Wilde, New York, Harper and Row Publishers, 1989, p. 821. Doy una versión algo libre del poema: «El marchito cáliz del lilio cae / en torno a su pistilo de oro polvoriento / y en el bosquecillo, sobre las hayas, / la última paloma torcaz arrulla y llama. / Leonino el girasol de brillantes colores / pende negro y desnudo de su tallo, / y por el sendero ventoso del jardín / las hojas muertas se dispersan, hora tras hora. / El soplo del viento acumula los pálidos pétalos de la alheña, / blanca como la leche, formando una masa nívea. / Yacen las rosas sobre la hierba, / como diminutos jirones de seda carmesí». 


\section{Un JARDÍN UMbrío DE ÉPOCA NAZARÍ: ANTONIO de ZAYAS}

Entre los escritores modernistas más interesados por las artes plásticas ocupó un lugar principal Antonio de Zayas. La colección de sonetos ecfrásticos titulada Retratos antiguos (1902) le sitúa -junto a Manuel Machado- entre los máximos cultores de la transposition d'art a comienzos del siglo XX. Heredero de la mejor tradición parnasiana, la obra del duque de Amalfi recibió los elogios de un crítico tan influyente como Manuel Bueno, que publicaba el siguiente juicio en La Correspondencia de España:

Zayas no es precisamente un evocador de imágenes a la manera de Góngora, ni un poeta de ensueño como Gabriel Rossetti. Con tener del uno y del otro el sentido pictórico, que asocia y funde la línea y la idea en el crisol de la rima; Zayas es una personalidad aparte. Al primero le tengo por el más rico y portentoso artífice del idioma. El segundo me parece un sentimental frustrado que se refugió en el arte de la Edad Media por horror al prosaísmo contemporáneo. Simultáneamente he leído los dos libros, Retratos antiguos de Zayas y Poems de Dante Gabriel Rossetti. También el poeta inglés se singulariza por su sensibilidad de pintor y también ha compuesto muchos sonetos inspirados en cuadros; pero su temperamento y su estética difieren del temperamento y de la estética de Zayas. Éste es un visual, aquel un imaginativo $^{110}$.

El citado párrafo se antoja revelador por varias razones. En primer lugar, a los ojos de sus coetáneos, la predilección de Zayas por una forma clásica como el soneto remite, a un tiempo, al magisterio de los Trophées de Heredia y a la mejor tradición áurea hispana, representada por la poesía de Góngora. En segundo lugar, el ejercicio de la écfrasis en la España de la época se asocia de forma habitual a los postulados de la Hermandad Prerrafaelita, en especial al modelo inter-artístico de los Sonnets for pictures de Dante Gabriel Rossetti. Por último, la profunda relación de la escritura zayiana con la pintura permitiría identificar al aristocrático personaje como un «poeta visual».

A zaga de dicha reflexión, conviene ahora detenerse brevemente en un soneto publicado entre las páginas de un volumen de evocador título: Reliquias (1910). La composición presenta un encuadre muy similar al de algunos lienzos de Rusiñol o Sorolla y está dedicada al espacio decadente y opresivo de los antiguos jardines nazaríes (En el bosque de la Alhambra):

La vieja fuente del jardín umbrío, con aleyas coránicas decora el tosco borde del tazón, que llora de silenciosas lágrimas un río.

En un ciprés, del ruiseñor el pío comenta el tedio de la raza mora, y muestra el negro rostro la albacora entre las pencas del nopal bravío.

Asomado a gemelos ajimeces que alicataran ninfas musulmanas bajo la sombra de historiado cedro,

110. Según la práctica más extendida en la época, Zayas recogió la reseña entre las páginas finales del libro Paisajes, Madrid, Imprenta de A. marzo, 1903, p. 276-284. El fragmento citado se localiza en p. 282-283. 
suben mi pecho a acongojar las preces que dispersan las fúnebres campanas de la torre mudéjar de San Pedro ${ }^{111}$.

De algún modo, el poema se inscribe en la consabida identificación entre el espacio cercado del jardín antiguo y la expresión flébil y entristecida del yo lírico («las preces [de] las fúnebres campanas suben a acongojar mi pecho»). Como corresponde a un orfebre del verso, el poco logrado virtuosismo de los versos se aprecia en el uso casi obsesivo del léxico de procedencia arábiga: «aleyas», «albacora», «ajimeces», «alicatar». El vocabulario se ve, además, reforzado por signos de tipo cultural o antropológico, referidos a la fisionomía y la religión: "coránicas», «raza mora», «musulmanas», «mudéjar» ${ }^{112}$. A mi juicio, el interés del soneto reside en el tipo de encuadre elegido, ya que permite establecer algunos paralelos con los senderos ya examinados del jardín visual. Al hablar de la pintura intimista de Sorolla, tuvimos ocasión de apuntar la importancia que asumen las fuentes del entorno nazarí en su obra. De hecho, este mismo tipo de composición (con la fuente en primer plano, los cipreses y el ambiente umbrío) puede reconocerse en lienzos como el titulado Fuente de Granada, donde aparecen recogidas las esencias del motivo andalusí (fig. 13).

Fig. 13. Una fuente, Granada (1917).

Óleo sobre lienzo.

Museo Sorolla

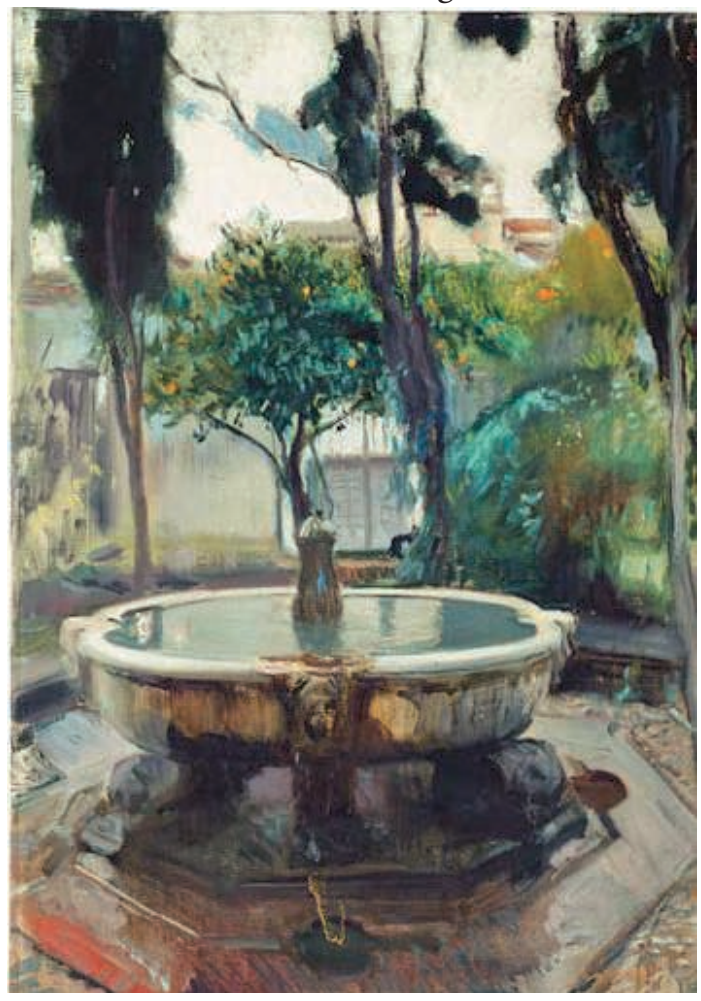

111. Antonio de Zayas, Obra poética, Amelina Correa (éd.), Sevilla, Fundación José Manuel Lara, 2005, p. 206.

112. Sobre la temática de Oriente en la obra del aristócrata, puede verse el estudio de Carlos Primo, "Calas en torno a la visión orientalista de Antonio de Zayas», Dicenda, 28, 2010, p. 153-184. 
El mejor amigo de Zayas, bullicioso compañero de tertulias y experimentos literarios, Manuel Machado, alabó en la prensa de la época algunos de libros poéticos ${ }^{113}$. Uno de los juicios del autor de Apolo. Teatro pictórico puede aducirse ahora para valorar este tipo de composición imbuida de valores plásticos: «los Paisajes de Zayas -aparte ser pinturas hermosísimas- tiene un alma, inseparable ya del alma del poeta, que nos canta sus contemplaciones; sonríen, hablan, nos alegran o melancolizan ${ }^{114}$. En términos semejantes se expresaría Emilia Pardo Bazán: «Paysages, ce sont des visions lumineuses d'Andalousie, de sévères caux-fortes castillanes, de pensifs tableaux de jardins, des intérieurs d'église où bruissent des prières d'un mysticisme ardent» ${ }^{115}$.

\section{Dos autores epigonales: Francisco Arévalo y Fernando López Martín}

Más allá del interés indudable que presentan las variaciones en torno al motivo del jardín en la obra de los grandes autores de la «nueva poesía» durante los años iniciales del Novecientos (los hermanos Machado, Juan Ramón Jiménez, el parnasiano Zayas) para comprender el alcance de esta veta temática conviene asomarse también a los escritos de algunos poetas que la historiografía literaria apenas ha atendido. En primer lugar, nos ocuparemos aquí de un escritor andaluz hoy apenas conocido, Francisco Arévalo. En el volumen Ensueños se halla el políptico titulado El poema del jardín. A través de un curioso ciclo de seis sonetos se despliega la visión arevaliana de este espacio simbólico: La dama, El galán, La fuente, Las flores, La luna, El viento. Desde el punto de vista de la construcción de un entorno melancólico, semejante a los ya examinados, quizá la composición más interesante sea la dedicada a las flores:

\footnotetext{
En el misterio de la tibia tarde, cuando agobiado el sol busca su ocaso, la hermosa Primavera se abre paso por el viejo jardín, con regio alarde.

Luz da su sangre, que en las rosas arde con un incendio de pulido raso, y de su seno tiembla el blanco vaso como azucena que a volcarse aguarde.

Las campanillas del umbral se mecen si los frescos claveles estremecen sus discos rebosantes de colores.
}

113. A la poesía -imbuida de valores plásticos- de ambos escritores ha dedicado un interesante análisis comparativo Eloy Navarro Domínguez, «La pintura como referente en Manuel Machado y Antonio de Zayas", Crisol de estudios filológicos, Stefan Ruhstaller (ed.), Huelva, Universidad de Huelva, 1995, p. 241-286.

114. Manuel Machado, "Los Paisajes de Antonio de Zayas», Impresiones. El Modernismo. Artículos, Crónicas y Reseñas (1899-1909), Rafael Alarcón Sierra (ed.), Valencia, Pre-Textos, p. 353-357 (la cita en p. 354).

115. "Le mouvement littéraire en Espagne. Les poètes espagnols du XXe siècle», Obras completas, Harry L. Kirby (ed.), Madrid, Aguilar, 1973, t. III, p. 1274-1281 (p. 1280). 
Y siente el alma, cuando ya se aleja, la dulzura de un sueño que se deja perdido en el encanto de las flores ${ }^{116}$.

Como puede apreciarse, el soneto se abre tímidamente a determinadas obsesiones temáticas del Simbolismo («misterio», «ocaso», «viejo jardín», «la dulzura de un sueño»), cuyo poso se aprecia también en el empleo de una figura como la alegoría (la «hermosa Primavera» camina sobre el jardín florido y vierte su «sangre» luminosa).

Este fugaz recorrido por los jardines crepusculares de la poesía de entresiglos se concluye ahora con la evocación de un libro de poemas del escritor tardomodernista Fernando López Martín: Oraciones paganas (Madrid, Imprenta Alburquerque, 1918). El interés de este autor olvidado por la écfrasis se hace evidente en la sección que rubrica como Joyas de la pintura, donde pergeña cuatro sugestivos lienzos verbales: Diana cazadora de Rubens (Museo de Múnich), Las tardes de Verano de Van Artois (Museo de Bruselas), la Susana en el baño de Guercino (Museo del Prado) y La rendición de Breda de Velázquez (Museo del Prado ${ }^{117}$. Esta personal selección de obras incluye un cuadro de paisaje (Van Artois) y nada menos que tres tableaux d'histoire, según todas las posibles modalidades del género (la bíblica de Guercino, la mitológica de Rubens y la político-militar de Velázquez). Por cuanto ahora nos interesa, López Martín remite a la boga decadentista en el poema El jardín abandonado:

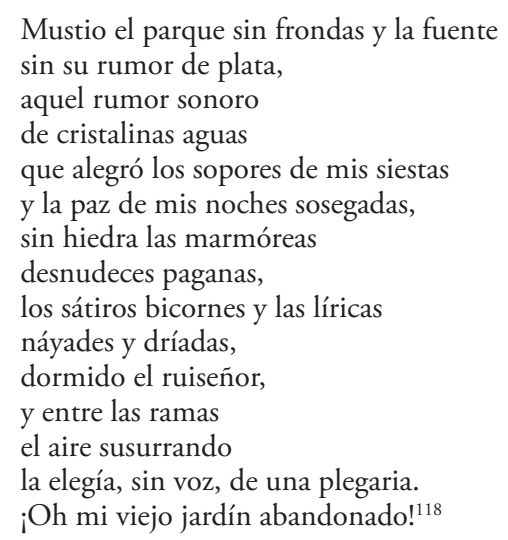

Al igual que J. R. Jiménez o Rusińol, el poeta ofrece condensados en la primera sección del poema los elementos habituales de un "Jardín de elegías" o de un «tableautin d'un charme elégiaque». Al acometer la pintura poética, delimitando un espacio simbólico lleno de antiguos recuerdos, cobran especial relevancia los sintagmas privativos: «sin frondas», «sin rumor», «sin hiedra»,

116. Francisco Arévalo, Ensueños, Córdoba, Imprenta de la Actividad, 1914, p. 110.

117. Los poemas se localizan en las pp. 17-20, 41-42, 49-50 y 65-66, respectivamente.

118. Oraciones paganas, Madrid, Imprenta Alburquerque, 1918, p. 13-16. El texto se dilata a través de siete estrofas, de las que se copian aquí solamente los versos iniciales. 
«sin voz». Todos los signos de este hortus conclusus hablan de la decadencia y la postración: «mustio parque». Envuelto en profundo silencio, el jardín está compuesto de "glorietas de penumbras y de ensueño», lo recorren «hondas veredas solitarias», que sumen al yo lírico en la languidez y el abandono. Tanto el título de la composición como la exclamatio retórica que cierra esta sección del poema ( $i \mathrm{Oh}$ mi viejo jardín abandonado!») podrían verse bajo el signo de un tácito homenaje al modelo (pictórico y literario) de Rusiñol.

\section{SIMBOLISTA Y DECADENTE: HACIA UNA TIPOLOGÍA DEL JARDÍN FINISECULAR}

Unos cuantos motivos fundamentales poblaron el imaginario de los creadores del fin-de-siécle: el centauro, la femme fatale, el andrógino, el jardín, la ciudad muerta, el esoterismo... Como acabamos de ver, en la importante serie de los Jardines de España de Rusiñol así como la todavía insuficientemente conocida colección de jardines andaluces y madrileños de Sorolla podrían reconocerse dos de los más importantes correlatos plásticos de algunas piezas líricas de los Machado, Eduardo Marquina, Juan Ramón Jiménez o Antonio de Zayas ${ }^{119}$. De hecho, bastaría con asomarse a la incidencia del término «jardín» en los títulos de algunos libros del momento para pulsar la atracción que el asunto ejerció sobre los autores finiseculares. Por Francia, España, Argentina o México se extendió esta moda de fuerte raíz plástica: Le jardin des rêves (1880) de Laurent Tailhade; Au jardin de l'infante (1893) de Albert Samain; Jardines lejanos (1904) de Juan Ramón Jiménez; Le jardin des supplices (1898) de Octave Mirbeau; Le jardin des ronces (1902) de Frédéric-Auguste Cazals; Los crepuisculos del jardin (1905) de Leopoldo Lugones; Los jardines interiores (1905) de Amado Nervo; las prosas poéticas de Pensées des jardins (1906) de Francis Jammes; los Jardines bajo la lluvia del cordobés Paulino Fernández Vallejo (1918)... En esa misma órbita de los jardines líricos en decadencia se movía asimismo la colección de sonetos de Julio Herrera y Reissig titulada los Parques abandonados, que recoge composiciones escritas entre 1900 y 1908. Desde el ámbito musical, cabe señalar asimismo el homenaje que Manuel de Falla quiso rendir a Santiago Rusiñol con Noche en los jardines de España (1916), para orquesta y piano.

$\mathrm{Al}$ indagar en el alcance profundo de un motivo como el del jardín abandonado -o su afín, el parque en decadencia- en la literatura de entresiglos conviene apuntar cómo aquel se vincula de manera muy estrecha al desarrollo temático de la Ciudad muerta, magistralmente fijado en palabra por Georges Rodenbach y por Fernand Khnopff en imagen ${ }^{120}$. Por supuesto,

119. Sobre las coordenadas del Simbolismo en España, puede consultarse el iluminador estudio de Rafael Alarcón Sierra, «Valores simbolistas en la literatura espańola del primer tercio del siglo XX", Anales de Literatura Española, 15, 2002, p. 71-92. En torno a la interrelación de las artes, véanse especialmente las p. 79-80.

120. Miguel Ángel Lozano Marco, "Un topos simbolista: la ciudad muerta», Imágenes del pesimismo. Literatura y Arte en España 1898-1930, Alicante, Universidad de Alicante, 2000, p. 11-46. Rafael García Pérez, «Interpretaciones del tópico de la ciudad muerta en la poesía 
el eco de tales modelos también llegó a España: en la península habría de producirse un fenómeno semejante en la múltiple "visión de Granada» que varios autores dieron según «los parámetros simbolistas de la ciudad muerta, ensimismada, silenciosa y abandonada, al margen por completo del tiempo y del caos que impone la modernidad ${ }^{121}$. Al erigirse en uno de los núcleos principales del motivo de la ville morte por predios hispánicos, la atmósfera decadente de la ciudad andaluza no sólo atrajo a pintores y poetas que cantaron la urbe y su decaído palacio nazarí, sino que también exaltaron sus jardines exhaustos Rusiñol, Sorolla, Manuel Machado, Juan Ramón Jiménez o Zayas, contemplando todos ellos con óptica afín la melancolía y soledad del Generalife ${ }^{122}$. El espíritu que late en muchos textos e imágenes sobre el motivo del jardín podría verse reflejado en la composición con la que Amado Nervo abriera el libro Los jardines interiores, bajo el significativo título Expone la indole del libro. Allí pueden leerse afirmaciones del tenor siguiente: «Hay savia enferma, / sangre doliente, / savia tardía, / que cuando brota, las ramazones del árbol cubre / con hojas mate, con hojas tenues... Tal es la mía. / Tal es la mía: savia del yermo, que sólo encubre / gérmenes locos de la futura yema insalubre, / y tiene pompa, mas es la pompa solemne y triste del viejo octubre» ${ }^{123}$. Al aire de estos versos lánguidos puede reconocerse cómo bajo el motivo del jardín se agazapan varias obsesiones temáticas de los creadores modernistas: el paso

francesa y espańola», Çédille, 4, 2008, p. 119-130 (en especial, pp. 128-129). Alargando un tanto el arco geográfico, en el contexto de la Europa meridional, no puede olvidarse -por citar otro testimonio ilustre- la importancia que asumió durante aquella época convulsa la serie de poesías reunidas por D’Annunzio bajo el título de Le città del silenzio (1904). El ciclo del gran maestro del Decadentismo se abría con unos versos en elogio de Ferrara: «O deserta bellezza di Ferrara, / ti loderò come si loda il vólto/ di colei che sul nostro cuor s'inclina / per aver pace di sue felicità lontane; / e loderò la chiara / sfera d'aere e d'acque / ove si chiude / la tua melanconia divina / musicalmente». Como se puede apreciar, el fragmento citado fija el perfil de una ciudad célebre por sus jardines interiores, casi secretos. El paisaje urbano ferrarés se identifica como «deserta bellezza» que vive en una «sfera d'aere e d'acque» y encierra una «melanconia divina» de signo musical. De manera semejante, el imaginario dannunziano perpetuó poéticamente la agonía espléndida de ciudades silentes como Pisa, Ferrara o Ravenna, tal como hicieran José María de Heredia y Albert Samain en sus Villes mortes, o Barrès en La mort de Venise.

121. Rafael Alarcón Sierra, prólogo a Impresiones. El Modernismo (artículos, crónicas y reseñas), Valencia, Pre-Textos, 2000, p. 41.

122. "La melancolía se proyecta sobre espacios -viene al caso el recuerdo del juanramoniano jardin enfermo de Arias tristes (1903)- y objetos inanimados: viejas callejuelas, plazas de piedra antigua, casas arruinadas de las ciudades muertas donde moran seres taciturnos, constituyen estampas recurrentes [...]. Reducido a un ámbito menor, se recrea el motivo en numerosos poemas consagrados a jardines enfermos y naturaleza muerta, sobre los cuales se refleja la tristeza del poeta». José María Ferri Coll, «Musa enferma: la melancolía en la poesía española de Fin de Siglo», Frenia, IX, 2009, p. 53-69. Sobre la melancolía andaluza elevada a categoría estética y color del ánimo que tiñe la visión del mundo, puede consultarse el ensayo reciente de Miguel Ángel García, Melancolía vertebrada. La tristeza andaluza del Modernismo a la Vanguardia, Barcelona, Anthropos, 2012 (en especial, el capítulo segundo «La tristeza andaluza: genealogía modernista», p. 65-116).

123. Amado Nervo, Plenitud. Perlas negras. Misticas. Los jardines interiores. El estanque de los lotos (ed. Ernesto Mejía Sánchez), México, Editorial Porrúa, 2001, p. 113. 
del tiempo, la decadencia, la melancolía, el abandono, la soledad, el esplendor sombrío de lo caduco y la muerte.

Con pleno acierto se ha señalado que el ejercicio de la transposition d'art responde a parámetros distintos según las corrientes que lo originan: existen significativas diferencias de enfoque entre la écfrasis de un cuadro de Jean-Léon Gérôme ejecutada por José María de Heredia entre los Parnasianos y la descripción lírica de una escena decadente de Beltrán Massés hecha por un autor más tardío como Armand Godoy ${ }^{124}$. En cuanto atañe al motivo del jardín, conviene matizar que «l'écriture symboliste de la peinture implique un dépassement de la fonction référentielle de la peinture et du langage». En efecto, «la nature de l'objet joue un rôle central dans la traduction [inter-artistique]». Como se acaba de sugerir, la écfrasis de las pinturas del Academicismo solemne del Ochocientos (el mal llamado art pompier) respondería a un impulso exclusivamente descriptivo, en tanto que la transposition d'art de los lienzos simbolistas y decadentes parecería responder a un estímulo de naturaleza más evocadora y sugestiva. La crítica más reciente trataba de establecer así una distinción doble : "Qualifions de descriptive et de suggestive deux façons opposées de traduire l'art pictural: la première décrit les œuvres le plus fidèlement possible, réfletant ainsi la fonction imitative de la peinture réaliste ; la seconde évoque les tableaux de la manière la plus allusive qui soit, faisant par là écho à la dimension poétique de la peinture suggestive» ${ }^{125}$.

Tanto en pintura como en poesía, los elementos del jardín se mueven en torno a una escenografía esencial: los árboles, la fuente, el agua y sus reflejos, la luz, las flores, ocasionalmente las esculturas de signo pagano... En los versos de Wilde, Machado o Juan Ramón Jiménez se aprecia a menudo una verdadera «dimension picturale du langage [poétique]» ${ }^{126}$, reconocible en la atención sintomática que prestan a detalles como el juego entre las luces y la sombra, así como la dispar paleta del cromatismo empleado. Tampoco debe olvidarse que entre la segunda mitad del Ochocientos y las primeras décadas del siglo XX, al igual que puede hallarse un grupo de literatos que ha gozado de una intensa formación pictórica ${ }^{127}$ (como es el caso de Jiménez), también se produjo el fenómeno inverso, de forma que algunos pintores que cosecharon grandes éxitos con sus lienzos también obtuvieron algún renombre como poetas. Baste aducir el caso de Jules Breton en ámbito francés, el de Dante Gabriel Rossetti

124. Jesús Ponce y Carlos Primo, "Armand Godoy o la écfrasis decadente», Analecta Malacitana, 32, Junio 2012, pp. 133-153.

125. Françoise Lucbert, Entre le voir et le dire. La critique d'art des écrivains dans la presse symboliste en France de 1882 à 1906, Rennes, Presses Universitaires de Rennes, 2005, p. 219 y 215.

126. Ibidem, p. 215.

127. En ámbito europeo se han publicado algunos importantes trabajos comparatistas sobre este asunto. Me limitaré aquí a espigar dos de los más recientes: AA. VV., Auf einem Anderen Blatt Dichter als Maler, Zürich, 2002; AA. VV., L’un pour l'autre. Les écrivains dessinent, Paris, Les Cahiers dessinés, 2008. 
en la Inglaterra victoriana, el de Santiago Rusiñol en Cataluña o el de Filippo De Pisis por predios itálicos ${ }^{128}$.

Desde el punto de vista de la elaboración de la forma, lejos de hallarnos ante meros ejemplos de descripción plana, el empleo del apóstrofe y la prosopopeya nos sitúan ante un proceso de humanización del espacio, que se erige en confidente o interlocutor del yo lírico, recogiendo sus meditaciones y sus penas. Según los cauces simbolistas, el jardín se configura como un verdadero "paisaje del alma», poblado por "palabras de sombra, música de silencio, seres de bruma ${ }^{129}$. En cuanto a la arquitectura textual que preside con asiduidad tales textos, hay que subrayar la importancia que asume en muchos de ellos la estructura circular, cuyo estatismo característico se condice bastante bien con unos poemas afines a la estrategia clásica de la écfrasis.

Entre 1895 y 1920 el espacio del jardín proporcionó una atalaya magnífica (a pintores y poetas) para meditar acerca del paso del tiempo y el suntuoso triunfo de la muerte. Varios marcadores temporales incidirían en esta lectura: al considerar la importancia de las estaciones, puede apreciarse la inequívoca predilección de los creadores modernistas por el otońo -en primer lugar- y el invierno -en segundo término ${ }^{130}$. De manera semejante, entre los momentos del día ninguno asume tanta importancia como el crepúsculo vespertino. Los cuaterniones que relacionan las estaciones del año (primavera, verano, otoño, invierno) con las horas del día (mañana, mediodía, tarde, noche) y las edades del hombre (infancia, juventud, madurez, senectud) permiten entrever cómo la elección del crepúsculo y el otońo se definen como signos de la melancolía del yo lírico, meditativo y maduro, envejecido prematuramente, que entrevé en estos paisajes íntimos su inminente decadencia, el atisbo de la muerte cercana. De alguna manera, podría verse en estos paisajes del alma, en el espacio lánguido del jardín abandonado, otra posible cifra y signo del mal de siglo ${ }^{131}$.

128. Sobre la lírica bretoniana puede verse la escueta presentación trazada por Aaron Schaffer, «Jules Breton, Parnassien», Modern Language Notes, 47, 8, 1932, p. 510-514. Por otro lado, contamos hoy con una interesante edición moderna de los versos de De Pisis: Poesie, Giovanni Raboni (éd.), Milano, Garzanti, 2003.

129. Enrique Gómez Carrillo, El tercer libro de las Crónicas, Madrid, Editorial Mundo Latino, 1921, p. 12. Sobre el interés de Gómez Carrillo por las relaciones inter-artísticas, puede consultarse el trabajo de María José Sueza Espejo, «La vida parisiense de Enrique Gómez Carrillo: interconexión de la literatura con las otras artes», Littérature, langages et arts. Rencontres et création, Huelva, Universidad de Huelva, 2007, p. 1-9.

130. Desde una óptica comparatista, puede verse el interesante conjunto de estudios reunido por Alain Montandon: L'Automne, Clermont-Ferrand, Presses Universitaires Blaise Pascal, 2007. Para la cronología que nos ocupa resultan de especial interés las páginas consagradas a Jean Lorrain y a la pintura simbolista (p. 159-186).

131. Por supuesto, el propósito del estudio nos ha llevado a insistir en las importantes conexiones entre el desarrollo pictórico del motivo y la fortuna del mismo en el ámbito estrictamente poético. Ahora bien, como apunta con magistral criterio Mercedes Blanco, «no todos esos jardines» se asocian de forma homogénea al universo de los «decadentes», ya que "quizá habría que distinguir entre lo lúgubre e inquietante, de un romanticismo exasperado hasta lo fantástico (el Jardín negro de Manuel Machado); la noble decadencia de los antiguos jardines descuidados o simplemente solitarios como los del Generalife o de Aranjuez (tipo melancolía de 
En suma, sin ánimo de agotar las sugestivas claves que reviste este motivo complejo en la poesía y la pintura de entre-siglos, el propósito de nuestro estudio no ha sido otro que acotar el recorrido temporal y simbólico del jardín en decadencia, atendiendo por vez primera tanto a los grandes nombres del momento (Rusiñol, Sorolla, Jiménez, los Machado) como a las figuras hoy consideradas menores (Zayas, López Martín, Arévalo). El trazado inicial que aquí se plantea deberá ser completado con el examen de otros lienzos y poemas en indagaciones posteriores.

\section{Indice de figuras}

1. Diego de Silva y Velázquez, Jardín de Villa Médici (Pabellón de Ariadna y Loggia). Óleo sobre lienzo, 44, 5 x 38, $5 \mathrm{~cm}$. y 48,5 x $43 \mathrm{~cm}$. (Museo del Prado).

2. Santiago Rusiñol, Soledad. Granada. Óleo sobre lienzo, 97 x $77 \mathrm{~cm}$. (colección particular).

3. Santiago Rusiñol, Jardín de las elegías. Óleo sobre lienzo, 101,5 x 127,5 cm. (colección particular).

4. Santiago Rusiñol, Jardín de Aranjuez con el fauno viejo. Óleo sobre lienzo, 117 x 146 cm. (Museo Nacional-Centro de Arte Reina Sofía).

5. Santiago Rusiñol, Jardines Monforte (Valencia). Óleo sobre lienzo (colección BBVA).

6. Joaquín Sorolla, Jardín de los adarves (Alhambra). Óleo sobre lienzo, 81 x 105 (colección particular).

7. Joaquín Sorolla, Fuente y jardín de la Alcazaba (Granada). Óleo sobre lienzo, 64,5 x 96 (Museo Sorolla).

8. Jardín de Lindaraja, la Alhambra. Óleo sobre lienzo, 105 x $82 \mathrm{~cm}$. (Museo Sorolla).

9. Joaquín Sorolla, Alberca del Alcázar de Sevilla. Óleo sobre lienzo, 82,5 x 105,5 cm. (Museo Sorolla).

10. Joaquín Sorolla, Retrato de Juan Ramón Jiménez. Óleo sobre lienzo.

11. Joaquín Sorolla, Retrato de Juan Ramón Jiménez. Óleo sobre lienzo (Hispanic Society of America).

12. Joaquín Sorolla, Jardín del Alcázar de Sevilla en invierno. Óleo sobre lienzo, $104 \times 73 \mathrm{~cm}$. (colección particular).

13. Joaquín Sorolla, Fuente de Granada. Óleo sobre lienzo, 95 x 64,5 cm. (Museo Sorolla).

las ruinas); el jardín otoñal o invernal, en que se echan de menos las bellezas de la vegetación para las que el jardín parece pensado y en el que el paisaje cobra matices sombríos alusivos a lo trágico de toda vida; el jardín del que se desprende la tristeza de la banalidad, de la pobreza provinciana, del descuido". 